University of Wollongong

Research Online

Australian Institute for Innovative Materials -

Papers

Australian Institute for Innovative Materials

$1-1-2016$

\title{
Self-assembled 3D foam-like NiCo2o4 as efficient catalyst for lithium oxygen batteries
}

Lili Liu

Nanyang Technological University, Singapore

Jun Wang

University of Wollongong, jw707@uowmail.edu.au

Yuyang Hou

University of Wollongong, yh879@uowmail.edu.au

Jun Chen

University of Wollongong, junc@uow.edu.au

Hua-Kun Liu

University of Wollongong, hua@uow.edu.au

See next page for additional authors

Follow this and additional works at: https://ro.uow.edu.au/aiimpapers

Part of the Engineering Commons, and the Physical Sciences and Mathematics Commons

Research Online is the open access institutional repository for the University of Wollongong. For further information contact the UOW Library: research-pubs@uow.edu.au 


\title{
Self-assembled 3D foam-like NiCo204 as efficient catalyst for lithium oxygen batteries
}

\begin{abstract}
A self-assembled 3D foam-like NiCo2O4 catalyst has been synthesized via a simple and environmental friendly approach, wherein starch acts as the template to form the unique 3D architecture. Interestingly, when employed as a cathode for lithium oxygen batteries, it demonstrates superior bifunctional electrocatalytic activities toward both the oxygen reduction reaction and the oxygen evolution reaction, with a relatively high round-trip efficiency of $70 \%$ and high discharge capacity of $10137 \mathrm{mAh}$ g-1 at a current density of $200 \mathrm{~mA} \mathrm{~g}-1$, which is much higher than those in previously reported results. Meanwhile, rotating disk electrode measurements in both aqueous and nonaqueous electrolyte are also employed to confirm the electrocatalytic activity for the first time. This excellent performance is attributed to the synergistic benefits of the unique 3D foam-like structure and the intrinsically high catalytic activity of $\mathrm{NiCo} 2 \mathrm{O} 4$.
\end{abstract}

\section{Keywords}

foam, like, nico2o4, efficient, 3d, catalyst, self, lithium, oxygen, batteries, assembled

Disciplines

Engineering | Physical Sciences and Mathematics

\section{Publication Details}

Liu, L., Wang, J., Hou, Y., Chen, J., Liu, H., Wang, J. \& Wu, Y. (2016). Self-assembled 3D foam-like NiCo2o4 as efficient catalyst for lithium oxygen batteries. Small, 12 (5), 602-611.

\section{Authors}

Lili Liu, Jun Wang, Yuyang Hou, Jun Chen, Hua-Kun Liu, Jiazhao Wang, and Yu-Ping Wu 


\section{WILEY-VCH}

Self-assembled 3D foam-like $\mathrm{NiCo}_{2} \mathrm{O}_{4}$ as Efficient Catalyst for Lithium Oxygen Batteries

Lili Liu, Jun Wang, Yuyang Hou, Jun Chen, Hua-Kun Liu, Jiazhao Wang*, and Yuping Wu*

[*]L. Liu, Dr. Prof. Y. Wu

New Energy and Materials Laboratory (NEML), Department of Chemistry \& Shanghai

Key Laboratory of Molecular Catalysis and Innovative Materials, Fudan University, Shanghai 200433, China

E-mail:wuyp@fudan.edu.cn

[*]L. Liu, J. Wang, Dr. Prof. H. Liu, Dr. A/Prof. J.Wang

Institute for Superconducting and Electronic Materials, University of Wollongong,

Wollongong, New South Wales 2522, Australia

E-mail: jiazhao@uow.edu.au

Y. Hou, Dr. A/Prof. J. Chen

Intelligent Polymer Research Institute, University of Wollongong, Wollongong, New South Wales 2522, Australia

Keywords: 3D foam-like, ORR, OER, overpotential, $\mathrm{Li}_{2} \mathrm{O}_{2}$

A self-assembled three-dimensional (3D) foam-like $\mathrm{NiCo}_{2} \mathrm{O}_{4}$ catalyst has been synthesized via a simple and environmental friendly approach, wherein starch acts as the template to form the unique 3D architecture. Interestingly, when employed as cathode for lithium oxygen batteries, it demonstrated superior bi-functional electrocatalytic activities towards both the oxygen reduction reaction and the oxygen evolution reaction, with a relatively high round-trip efficiency of $70 \%$ and high discharge capacity of $10137 \mathrm{mAh} \mathrm{g}^{-1}$ at a current density of 200 $\mathrm{mA} \mathrm{g}^{-1}$, which is much higher than those in previously reported results. Meanwhile, rotating disk electrode measurements in both aqueous and non-aqueous electrolyte were also employed to confirm the electrocatalytic activity for the first time. This excellent performance is attributed to the synergistic benefits of the unique 3D foam-like structure and the intrinsically high catalytic activity of $\mathrm{NiCo}_{2} \mathrm{O}_{4}$.

\section{Introduction}

Intensive research efforts worldwide are being devoted to the realization of a new generation of lithium oxygen batteries, as a result of their high theoretical specific energy, which is 


\section{WILEY-VCH}

almost ten times that of Li-ion batteries. ${ }^{[1,2]}$ Such batteries are the technology of choice for the electrification of transport and are expected to find application in static electricity storage, especially in grid distribution networks. ${ }^{[3]}$ Although the reaction mechanism of lithium oxygen batteries is simple and straightforward, the practical use of lithium oxygen batteries has been restricted by numerous scientific challenges, including high discharge-charge overpotential, low energy efficiency, poor rate capability, and especially short cycle life, which are caused by the sluggish kinetics of the oxygen reduction reaction (ORR) and the oxygen evolution reaction (OER). ${ }^{[4]}$ It has been demonstrated that the performance of $\mathrm{Li}-\mathrm{O}_{2}$ batteries is strongly determined by both the materials and the architecture of the oxygen electrodes, which contribute most of the voltage gap and cyclic capability of such batteries. ${ }^{[5]}$

Various catalysts have been studied for $\mathrm{Li}-\mathrm{O}_{2}$ batteries to overcome these challenges. ${ }^{[3,4,6-15]}$ Among them, $\mathrm{NiCo}_{2} \mathrm{O}_{4}$, a typical ternary spinel nickel cobalt oxide with the advantages of low cost, natural abundance, higher electronic conductivity than those of $\mathrm{Co}_{3} \mathrm{O}_{4}$ and $\mathrm{NiO}$, and especially good bi-functional catalytic activity towards the ORR and OER, has aroused much interest for use as an electrocatalyst for $\mathrm{Li}^{-\mathrm{O}_{2}}$ batteries. ${ }^{[16-20]} \mathrm{A} \mathrm{NiCo}_{2} \mathrm{O}_{4}$ nanowire array grown on carbon cloth was reported as cathode for $\mathrm{Li}^{-\mathrm{O}_{2}}$ batteries, but only a capacity of approximately $1000 \mathrm{mAh} \mathrm{g}^{-1}$ was delivered, which was because the active sites only exist on the tips of the $\mathrm{NiCo}_{2} \mathrm{O}_{4}$ nanowires. ${ }^{[21]}$ To achieve a higher capacity, Wang et al. synthesized mesoporous $\mathrm{NiCo}_{2} \mathrm{O}_{4}$ nanosheets via a hydrothermal method, and higher reversible capacity was demonstrated, as well as good cycling stability. ${ }^{[18]}$ Although enhanced electrocatalytical performances of $\mathrm{NiCo}_{2} \mathrm{O}_{4}$ have been reported, they are far from satisfactory, either due to low capacity or to high discharge-charge overpotential, ${ }^{[22]}$ which may be largely due to their unfavourable cathode structure.

Generally speaking, an ideal oxygen electrode requires a highly conductive and porous structure to facilitate both electron and oxygen transportation. ${ }^{[23-25]}$ Typically, in a lithium oxygen battery, the formation of $\mathrm{Li}_{2} \mathrm{O}_{2}$ only occurs on the triple junctions where electrolyte, 


\section{WILEY-VCH}

catalytic active sites, and oxygen coexist. The more tri-phase regions, the more $\mathrm{Li}_{2} \mathrm{O}_{2}$ will be produced, and therefore, higher capacity can be delivered from the battery. ${ }^{[21]}$ The threedimensional (3D) skeleton structure has drawn much attention for the design of the oxygen electrode, according to previous reports, due to the following advantages: ${ }^{[27,28]}$ a) it can provide suitable tunnels to supply continuous pathways for oxygen and meanwhile provide sufficient space for $\mathrm{Li}_{2} \mathrm{O}_{2}$ formation according to the triple-junction oxygen reduction process, b) it can increase the electrical conductivity of the electrode and facilitate the charge transfer and electrochemical kinetics, c) it can enlarge the contact area between the electrolyte and the electrode to deliver high capacity and rate capability. Inspired by the 3D architecture, nickel foam has been widely employed by researchers as a porous catalyst support for $\mathrm{Li}-\mathrm{O}_{2}$ batteries. ${ }^{[29]}$ Porous carbon derived from a graphene oxide gel in nickel foam was directly used as an $\mathrm{O}_{2}$ cathode, which facilitated a continuous $\mathrm{O}_{2}$ flow. ${ }^{[30]}$ Liu et al. reported $\mathrm{Co}_{3} \mathrm{O}_{4}$ grown on nickel foam with a $3 \mathrm{D}$ network structure as a cathode material for $\mathrm{Li}-\mathrm{O}_{2}$ batteries, and a voltage gap of no more than $0.5 \mathrm{~V}$ was achieved, which can be ascribed to the Ni foam skeleton, which provided continuous pathways for $\mathrm{O}_{2 \cdot}{ }^{\left[{ }^{29]}\right.}$ Although deposition of catalyst on nickel foam can form an interconnected porous structure, contact resistance still exists between the catalyst and the nickel foam, which inevitably causes overpotential during charge and discharge processes. ${ }^{[30,31]}$ Moreover, the pores and tunnels of the commercial nickel foam are large (usually $200 \mu \mathrm{m}$ in diameter), which correspondingly decreases the surface area of the catalyst loaded on it. Meanwhile, these too large pores are usually flooded by the electrolyte, forming two-phase instead of three-phase regions. ${ }^{[26]}$ Therefore, the development of a well-designed 3D foam-like cathode architecture by integrating small porous channels in it will be a good choice for enhanced $\mathrm{Li}-\mathrm{O}_{2}$ batteries. ${ }^{[33]}$

In this work, we used environmentally friendly starch as a template, and a self-assembled 3D foam-like $\mathrm{NiCo}_{2} \mathrm{O}_{4}$ framework with mesopores inside was obtained. It is expected that during discharge, the large macro-tunnels can function as "highways" to supply oxygen to the 


\section{WILEY-VCH}

interior parts of the cathode, while the mesopores on nanowalls are the "exits" to provide the triple junctions (solid-liquid-gas) required for the oxygen reduction reaction and act as centres for $\mathrm{Li}_{2} \mathrm{O}_{2}$ crystallization. ${ }^{[30]}$ Rotating disk electrode (RDE) measurements both in aqueous and non-aqueous electrolytes were employed to explore the electrocatalytical properties of the as prepared 3D foam-like $\mathrm{NiCo}_{2} \mathrm{O}_{4}$. Remarkably, the as-prepared hierarchically self-assembled 3D-structured $\mathrm{NiCo}_{2} \mathrm{O}_{4}$ manifested improved catalytic performance, with a high round-trip efficiency of $70 \%$ and a stable lifespan of 80 cycles for lithium oxygen batteries.

\section{Results and Discussion}

Soluble starch was used as the template for the fabrication of $3 \mathrm{D}$ foam-like $\mathrm{NiCo}_{2} \mathrm{O}_{4}$, and the process is schematically shown in Figure 1. It was reported that starch is a natural polysaccharide polymer with abundant hydroxyl groups, which can facilitate supramolecular associations by inter- and intramolecular hydrogen bonding. ${ }^{[35]} \mathrm{Co}^{2+}$ and $\mathrm{Ni}^{2+}$ cations, formed by the dissolution of nickel acetate and cobalt acetate in water, can thus favourably bind with the $-\mathrm{OH}$ containing groups on starch molecules when they are mixed together. ${ }^{[36]}$ Upon heating to $90{ }^{\circ} \mathrm{C}$, the aqueous dispersion of starch in a complex with $\mathrm{Co}^{2+}$ and $\mathrm{Ni}^{2+}$ became gel-like as a result of swelling and disruption of the starch granules. The resulting sponge-like pink gel consisted of a hydrated 3D porous network of predominantly amylose molecules. The as-prepared gel was directly dehydrated via a freeze-drying process to maintain the 3D architecture and then heated at $380^{\circ} \mathrm{C}$ for $5 \mathrm{~h}$ in air atmosphere. The final product from this process shows a black loose appearance with the same shape as the former gel. According to a previous report, ${ }^{[37]}$ the starch template can be completely removed at $380{ }^{\circ} \mathrm{C}$ in air.

In the process, the starch template plays two main roles in the formation of the $3 \mathrm{D}$ foam-like porous structure: Firstly, it prevents small $\mathrm{NiCO}_{2} \mathrm{O}_{4}$ units from growing into large particles before the decomposition of starch; secondly, the release of $\mathrm{CO}_{2}$ produced by the decomposition of the starch results in a large number of mesopores in the $\mathrm{NiCo}_{2} \mathrm{O}_{4}$ nanoparticles. Starch acts as not only as a template, but also as a passivated reagent. So, the 


\section{WILEY-VCH}

resultant $\mathrm{NiCo}_{2} \mathrm{O}_{4}$ possesses a $3 \mathrm{D}$ foam-like framework with continuous walls that consist of closely packed nanoparticles.

The structure of the as-prepared $3 \mathrm{D}$ foam-like $\mathrm{NiCo}_{2} \mathrm{O}_{4}$ was confirmed by X-ray diffraction (XRD), as shown in Figure 2. Remarkably, the peaks (20 values) at 31.1, 36.5, 44.6, 59.1, and $64.9^{\circ}$ correspond to the diffractions from the (220), (311), (400), (511), and (440) planes of spinel phase $\mathrm{NiCo}_{2} \mathrm{O}_{4}\left(\mathrm{JCPDS}\right.$ card no.73-1702). ${ }^{[15]}$

SEM images of the calcined $\mathrm{NiCo}_{2} \mathrm{O}_{4}$ reveal a $3 \mathrm{D}$ foam-like framework with continuous pores and walls that consist of closely packed nanoparticles (Figure 3a and 3b). X-ray spectroscopy (EDS) pattern conducted from the 3D foam-like $\mathrm{NiCo}_{2} \mathrm{O}_{4}$ is shown in Table $\mathbf{S 1}$ and Figure $\mathbf{S} 1$. Besides the $\mathrm{Al}$ and $\mathrm{C}$ peaks coming from the SEM holder and conductive adhesive tape, respectively, only the elements $\mathrm{Ni}$, $\mathrm{Co}$ and $\mathrm{O}$ are detected in the $\mathrm{EDS}$ spectrum. The composition analysis reveals that the stoichiometry elemental ratio of $\mathrm{Ni}$ : Co: $\mathrm{O}$ in the sample is nearly 1: 2: 4, which proves that the whole $3 \mathrm{D}$ foam-like $\mathrm{NiCo}_{2} \mathrm{O}_{4}$ structure consists of $\mathrm{NiCo}_{2} \mathrm{O}_{4}$. The TEM image (Figure 3c) also proves that the sample has obvious nano/mesoporous structure with interconnected nanoparticles. Nanowalls could also be observed in Figure $3 \mathrm{c}$ which are well consistent with the SEM images. It is noteworthy that besides the macro-sized foam-like structure, mesopores with a size of less than $8 \mathrm{~nm}$ can also be observed between the nanoparticles, and such mesopores have been reported to offer more diffusion pathways for oxygen and permit the electrolyte to easily penetrate, forming more of the triplephase (solid-liquid-gas phases) regions required for efficient ORR and OER reactions. ${ }^{[30-38]}$ The high-resolution TEM (HRTEM) image (Figure 3d) indicates that the particles possess a typical crystalline texture, with space between lattice planes of $0.242 \mathrm{~nm}$, which corresponds to the $d$ value of the (311) planes of spinel phase $\mathrm{NiCo}_{2} \mathrm{O}_{4}$.

The $\mathrm{N}_{2}$ adsorption-desorption isotherms collected at $77 \mathrm{~K}$ and the pore-size distribution are shown in Figure S2 in the Supporting Information. The nitrogen sorption curves of the asprepared $\mathrm{NiCo}_{2} \mathrm{O}_{4}$ exhibit the combined characteristics of type II/IV according to the IUPAC 


\section{WILEY-VCH}

classification, ${ }^{[30-39]}$ with a specific surface area of $46.4 \mathrm{~m}^{2} \mathrm{~g}^{-1}$ and a total pore volume of 0.26 $\mathrm{cm}^{3} \mathrm{~g}^{-1}$. The $\mathrm{H} 1$ hysteresis loop in the $\mathrm{P} / \mathrm{P}^{0}$ range of $0.6-1.0$ is indicative of mesoporosity. ${ }^{[39]}$ The pore-size distribution of the as-prepared $\mathrm{NiCo}_{2} \mathrm{O}_{4}$ calculated by the Barrett-JoynerHalenda (BJH) method (Figure S2b) shows a large distribution of mesopores at sizes less than $10 \mathrm{~nm}$ and at $50 \mathrm{~nm}$, respectively. These mesopores refer to the interspace voids between the aggregated nanoparticles, which can also be observed from the TEM results (Figure $3 \mathrm{~b}$ and 3c). This unique porous structure combined with the 3D foam-like tunnels could be an ideal design for an $\mathrm{O}_{2}$ electrode: ${ }^{[30]}$ during the discharge, the large tunnels can function as "highways" to supply oxygen to the interior parts of the cathode, while the mesopores on nanowalls are the "exits" that provide the triple junctions (solid-liquid-gas) required for the ORR reaction.

X-ray photoelectron spectroscopy (XPS) measurements were performed on the as-prepared $\mathrm{NiCo}_{2} \mathrm{O}_{4}$, and the corresponding results are presented in Figure 4. The XPS spectra indicate the presence of $\mathrm{Ni}, \mathrm{Co}$, and $\mathrm{O}$, as well as $\mathrm{C}$ from the graphite reference, and no other element peaks are detected (Figure $4 \mathrm{a}$ ). By using a component fitting method, the Ni $2 \mathrm{p}$ emission spectrum (Figure 4b) is reasonably deconvoluted into four peaks, with two spin-orbit doublets characteristic of $\mathrm{Ni}^{2+}$ and $\mathrm{Ni}^{3+}$, and one shake-up satellite (indicated as "Sat."). The binding energy peak at $855.6 \mathrm{eV}$ and its satellite peak at $872.5 \mathrm{eV}$ correspond to $\mathrm{Ni}^{2+}$ while the binding energy peak at $861.4 \mathrm{eV}$ and its satellite peak at $879.1 \mathrm{eV}$ correspond to the $\mathrm{Ni}^{3+}$. Similar to Ni $2 p$, the Co $2 p$ (Figure $4 \mathrm{c}$ ) was also fitted with two spin-orbit doublets and one shake-up satellite. Specifically, the fitting peaks at binding energies of 778.4 and $794.0 \mathrm{eV}$ are attributed to $\mathrm{Co}^{3+}$, whereas other fitting peaks sitting at 780.0 and $795.1 \mathrm{eV}$ are ascribed to $\mathrm{Co}^{2+} \cdot[13,40]$ The high resolution spectrum of the $\mathrm{O} 1 \mathrm{~s}$ region (Figure $4 \mathrm{~d}$ ) shows three oxygen contributions, which can be denoted as $\mathrm{O} 1, \mathrm{O} 2$, and $\mathrm{O} 3$, respectively. Usually, the $\mathrm{O} 1$ peak at $529.1 \mathrm{eV}$ is typical of metal-oxygen bonds, ${ }^{[13,40]}$ while the $\mathrm{O} 2$ peak located at $530.7 \mathrm{eV}$ is assigned to the $\mathrm{OH}^{-}$groups. The presence of this component in the $\mathrm{O} 1 \mathrm{~s}$ spectrum indicates 


\section{WILEY-VCH}

that the surface of the $\mathrm{NiCo}_{2} \mathrm{O}_{4}$ is hydroxylated to some extent due to either surface oxyhydroxide or the substitution for oxygen atoms at the surface by hydroxyl groups. ${ }^{[13,33]}$ The $\mathrm{O} 3$ contribution at $532.7 \mathrm{eV}$ is usually associated with defects, contaminants, and a number of surface species, including chemisorbed oxygen, under-coordinated lattice oxygen, or species intrinsic to the surface of the spinel. ${ }^{[13,41,42]}$ These above data show that the surface of the as-prepared 3D foam-like $\mathrm{NiCo}_{2} \mathrm{O}_{4}$ has a composition including $\mathrm{Co}^{2+}, \mathrm{Co}^{3+}, \mathrm{Ni}^{2+}$, and $\mathrm{Ni}^{3+}$, which may provide good electrocatalytic activity toward ORR/OER reactions.

The new 3D foam-like $\mathrm{NiCo}_{2} \mathrm{O}_{4}$ was subjected to linear sweep voltammetry (LSV) measurements on a rotating disk electrode $(\mathrm{RDE})$ in $\mathrm{O}_{2}$-saturated $0.1 \mathrm{M} \mathrm{KOH}$ at a scan rate of $10 \mathrm{mV} \mathrm{s}^{-1}$ in the potential range of $-0.9-0.1 \mathrm{~V}$ (vs. $\mathrm{AgCl} / \mathrm{Ag}$ ). Super $\mathrm{P}$ and standard commercial $\mathrm{Pt} / \mathrm{C}(10 \mathrm{wt} \% \mathrm{Pt}$ on Vulcan $\mathrm{XC}-72$ carbon) were tested as control samples. Compared with standard commercial Pt/C (Figure S3a) and Super P (Figure S3c), our asprepared 3D foam-like $\mathrm{NiCo}_{2} \mathrm{O}_{4}$ gives more defined diffusion-controlled LSV waves (Figure 5a). With increasing rotation speed, the limiting current density also increases. Furthermore, the limiting current density of the ORR on the $3 \mathrm{D}$ foam-like $\mathrm{NiCo}_{2} \mathrm{O}_{4}$ electrode is always higher than that of the Super P electrode and much more stable than that of standard commercial $\mathrm{Pt} / \mathrm{C}$ at each rotation rate, suggesting better ORR activity on the $3 \mathrm{D}$ foam-like $\mathrm{NiCo}_{2} \mathrm{O}_{4}$ electrode. ${ }^{[30]}$ The linearity of the Koutecky-Levich plots and the near parallelism of the fitting lines for the 3D foam-like $\mathrm{NiCo}_{2} \mathrm{O}_{4}$ electrode (inset of Figure 5a) suggest first order reaction kinetics toward the concentration of dissolved oxygen and similar electron transfer numbers for the ORR at different potentials. ${ }^{[43,44]}$ The electron transfer number $(n)$ was calculated to be 4.0 at $0.45-0.75 \mathrm{~V}$ from the slopes of the Koutecky-Levich plots, ${ }^{[36]}$ suggesting that the $3 \mathrm{D}$ foam-like $\mathrm{NiCo}_{2} \mathrm{O}_{4}$ favours a $4 \mathrm{e}^{-}$oxygen reduction reaction, as in the ORR catalysed by commercial Pt/C catalyst measured in the same $0.1 \mathrm{M} \mathrm{KOH}$ electrolyte ( $n$ $=4$ for Pt/C, see Supplementary Figure S3a and S3b), while Super P could only catalyse aa $2 \mathrm{e}^{-}$oxygen reduction reaction (see Supplementary Figure S3c and S3d). Figure 5b indicates 


\section{WILEY-VCH}

that the catalytic activity of the as-prepared 3D foam-like $\mathrm{NiCo}_{2} \mathrm{O}_{4}$ significantly outperforms that of Super $\mathrm{P}$ at a rotation speed of $1600 \mathrm{rpm}$, as evidenced by the positive shifts of the onset potential and the half-wave potential $\left(E_{1 / 2}\right)$ to -0.15 and $-0.34 \mathrm{~V}$ (vs. $\mathrm{AgCl} / \mathrm{Ag}$ ), respectively. In contrast, the values for the Super P are $-0.3 \mathrm{~V}$ and $-0.43 \mathrm{~V}$, respectively. Also, the diffusion current density of the $3 \mathrm{D}$ foam-like $\mathrm{NiCo}_{2} \mathrm{O}_{4}$ is notably stronger than that of Super P, suggesting synergistic effects on the ORR catalytic activity of 3D foam-like $\mathrm{NiCo}_{2} \mathrm{O}_{4}$.

We also extended the potential of the as-prepared 3D foam-like $\mathrm{NiCo}_{2} \mathrm{O}_{4}$ electrode and the control samples to $0.9 \mathrm{~V}$ (vs. $\mathrm{AgCl} / \mathrm{Ag}$ ) to the water oxidation regime and evaluated the electrocatalytic oxygen evolution reaction (OER) (Figure 5c). In $0.1 \mathrm{M} \mathrm{KOH}$, the 3D foamlike $\mathrm{NiCo}_{2} \mathrm{O}_{4}$ electrode offers a rather higher current density than Super P, with a value of 24 $\mathrm{mA} \mathrm{cm} \mathrm{cm}^{-2}$ and an onset potential of $0.6 \mathrm{~V}$. The above results show that the $3 \mathrm{D}$ foam-like $\mathrm{NiCo}_{2} \mathrm{O}_{4}$ is a powerful bi-functional catalyst for both oxygen reduction and oxygen evolution. ${ }^{[46]}$ Since the primary goal of this work is to develop an efficient ORR/OER catalyst for non-aqueous lithium oxygen batteries, the ORR activity of the $3 \mathrm{D}$ foam-like $\mathrm{NiCo}_{2} \mathrm{O}_{4}$ catalyst in $\mathrm{O}_{2}$-saturated $1 \mathrm{M} \mathrm{LiCF}_{3} \mathrm{SO}_{3}$ in tetraethylene glycol dimethyl ether (TEGDME) was also studied using RDE with a rotation speed of $1600 \mathrm{rpm}$ (Figure 5d). With a similar trend to the ORR activity measured in aqueous electrolyte, a significant improvement in the ORR activity was observed on the $3 \mathrm{D}$ foam-like $\mathrm{NiCo}_{2} \mathrm{O}_{4}$ catalyst compared to the Super $\mathrm{P}$ catalyst in terms of more positive onset and half-wave potential. These direct ORR and OER assessments indicate that the as-prepared $3 \mathrm{D}$ foam-like $\mathrm{NiCo}_{2} \mathrm{O}_{4}$ is a promising catalyst for Li- $\mathrm{O}_{2}$ batteries.

The cathode performance using an electrolyte containing $\mathrm{O}_{2}$-saturated $1.0 \mathrm{M} \mathrm{LiCF}_{3} \mathrm{SO}_{3}$ in TEGDME for the $\mathrm{Li}_{-} \mathrm{O}_{2}$ battery is shown in Figure 6. All the capacities reported in this work are normalized by the mass of carbon used in the cathodes. Cyclic voltammetry (CV) curves of the as-prepared 3D foam-like $\mathrm{NiCo}_{2} \mathrm{O}_{4}$ and Super $\mathrm{P}$ control sample (Figure 6a) show that 


\section{WILEY-VCH}

no redox phenomenon can be observed for the $3 \mathrm{D}$ foam-like $\mathrm{NiCo}_{2} \mathrm{O}_{4}$-based electrode in argon-saturated electrolyte, demonstrating the lack of any electrochemical reaction in such an atmosphere. Besides the more positive ORR peak potential, however, the as-prepared 3D foam-like $\mathrm{NiCo}_{2} \mathrm{O}_{4}$ exhibits an oxidation (OER) peak at $3.7 \mathrm{~V}\left(v s . \mathrm{Li}^{+} / \mathrm{Li}\right)$, corresponding to the decomposition of discharge products, while there is no oxidation peak for Super $\mathrm{P}$ electrode below $4 \mathrm{~V}\left(v s . \mathrm{Li}^{+} / \mathrm{Li}\right)$ in $\mathrm{O}_{2}$-saturated electrolyte. The first discharge and charge curves of a lithium oxygen battery with the $3 \mathrm{D}$ foam-like $\mathrm{NiCo}_{2} \mathrm{O}_{4}$-based electrode are compared with those of the pure Super P electrode at the same current density $\left(200 \mathrm{~mA} \mathrm{~g}^{-1}\right)$ in Figure $6 \mathrm{~b}$ to enable an understanding of the excellence of the $3 \mathrm{D}$ foam-like $\mathrm{NiCo}_{2} \mathrm{O}_{4}$ in terms of its ORR and OER kinetics. The lithium oxygen battery with the pure Super P sample exhibits a discharge and charge overpotential of 0.31 and $1.18 \mathrm{~V}$, respectively, with a low round-trip efficiency of $64 \%$. In contrast, the battery with the as-prepared 3D foam-like $\mathrm{NiCo}_{2} \mathrm{O}_{4}$ presents discharge-charge overpotentials of 0.2 and $0.97 \mathrm{~V}$, respectively, which results in a higher round-trip efficiency of $70 \%$. Additionally, the initial discharge capacity of the 3D foam-like $\mathrm{NiCo}_{2} \mathrm{O}_{4}$ electrode is $101376 \mathrm{mAh} \mathrm{g}^{-1}$, which is significantly higher than that of the Super P electrode (5928 $\left.\mathrm{mAh} \mathrm{g}^{-1}\right)$. To the best of our knowledge, this is the first report that a lithium oxygen battery with $\mathrm{NiCo}_{2} \mathrm{O}_{4}$-based catalyst shows such low dischargecharge overpotential with such a high specific capacity based on the mass of carbon. Also, in order to make sure that all the capacity has resulted from the oxygen reduction reaction instead of from lithium insertion into the $\mathrm{NiCo}_{2} \mathrm{O}_{4}$ electrode, discharge curves in traditional R2032 cells without $\mathrm{O}_{2}$ atmosphere were collected (See Supporting Information, Figure S4). A negligible capacity of $2 \mathrm{mAh} \mathrm{g}^{-1}$ could be delivered when the discharge potential was cut to $2.35 \mathrm{~V}$, suggesting that $\mathrm{NiCo}_{2} \mathrm{O}_{4}$ only functions as an oxygen reduction reaction catalyst.

Additionally, the rate performance of the $3 \mathrm{D}$ foam-like $\mathrm{NiCo}_{2} \mathrm{O}_{4}$ in comparison with Super $\mathrm{P}$ was further investigated at higher discharge current densities of 500 and $1000 \mathrm{~mA} \mathrm{~g}^{-1}$, respectively, when the discharge potential was cut to $2.35 \mathrm{~V}$ (Figure 6c and Supplementary 


\section{WILEY-VCH}

Figure S5a). A specific capacity of $8202 \mathrm{mAh} \mathrm{g}^{-1}$ was found for the $3 \mathrm{D}$ foam-like $\mathrm{NiCo}_{2} \mathrm{O}_{4}$ based electrode, while $4070 \mathrm{mAh} \mathrm{g}^{-1}$ can be delivered by the Super P electrode at a current density of $500 \mathrm{~mA} \mathrm{~g}^{-1}$. Even when the current density was increased to $1000 \mathrm{~mA} \mathrm{~g}^{-1}$, the capacity of the $3 \mathrm{D}$ foam-like $\mathrm{NiCo}_{2} \mathrm{O}_{4}$ still remained as high as $5598 \mathrm{mAh} \mathrm{g}^{-1}$, while the discharge plateau remained above $2.5 \mathrm{~V}$. The good rate capability is likely to have benefited from its unique structure: during the discharge, large amounts of oxygen can be supplied by the "highways" of the macro-tunnels and stored in the interior parts of the cathode, facilitating the rapid oxygen reduction reaction at high current densities. ${ }^{[30,38]}$

Figure 6d shows the typical initial discharge and charge profiles of the 3D foam-like $\mathrm{NiCo}_{2} \mathrm{O}_{4}$-based electrode and the Super P electrode with a fixed capacity of $1000 \mathrm{mAh} \mathrm{g}^{-1}$ and a current density of $200 \mathrm{~mA} \mathrm{~g}^{-1}$, from which a much lower discharge and charge overpotential can be observed for the 3D foam-like $\mathrm{NiCo}_{2} \mathrm{O}_{4}$-based electrode. Remarkably, the dischargecharge curves from the $5^{\text {th }}$ to the $30^{\text {th }}$ cycles even overlap (Figure 6e), and the specific capacity suffers no loss up to 80 cycles (Figure S5b) for the $3 \mathrm{D}$ foam-like $\mathrm{NiCo}_{2} \mathrm{O}_{4}$-based electrode, suggesting its good stability and reversibility. The stable cycling performance of the as-prepared $3 \mathrm{D}$ foam-like $\mathrm{NiCo}_{2} \mathrm{O}_{4}$-based electrode in comparison with the Super $\mathrm{P}$ electrode is also manifested by the terminal discharge-charge potential with a fixed capacity of $1000 \mathrm{mAh} \mathrm{g}^{-1}$ at a current density of $200 \mathrm{~mA} \mathrm{~g}^{-1}$. As shown in Figure 6f, after 80 cycles, the terminal discharge and charge potentials of the $\mathrm{NiCo}_{2} \mathrm{O}_{4}$-based electrode are $2.47 \mathrm{~V}$ and 4.35 $\mathrm{V}\left(v s . \mathrm{Li}^{+} / \mathrm{Li}\right)$, respectively, whereas, Super $\mathrm{P}$ electrode could only maintain such performance for less than 15 cycles. The better cycling stability of the $3 \mathrm{D}$ foam-like $\mathrm{NiCo}_{2} \mathrm{O}_{4}-$ based electrode than that of the Super P electrode demonstrates its promising application as an effective ORR and OER catalyst for lithium oxygen batteries.

To further understand the reaction mechanism of the $3 \mathrm{D}$ foam-like $\mathrm{NiCo}_{2} \mathrm{O}_{4}, \mathrm{XRD}$ measurements on the electrode at different discharge-charge stages of lithium oxygen batteries and examination of the morphologies of the electrode at corresponding stages were 


\section{WILEY-VCH}

also conducted. XRD patterns of the $\mathrm{NiCo}_{2} \mathrm{O}_{4}$ electrodes at different stages for the first cycle at a current density of $100 \mathrm{~mA} \mathrm{~g}^{-1}$ are shown in Figure 7a. Compared with the XRD pattern of the fresh electrode, new diffraction peaks could be observed for the discharged electrode. They can be assigned to the (100), (101), and (110) peaks of $\mathrm{Li}_{2} \mathrm{O}_{2}$ (as highlighted in Figure 7a). These peaks indicate that $\mathrm{Li}_{2} \mathrm{O}_{2}$ is a major crystalline discharge product. ${ }^{[47,48]}$ The three diffraction peaks disappeared when the battery was recharged, however, which suggests that the discharge product $\mathrm{Li}_{2} \mathrm{O}_{2}$ is decomposed during the charging process. Meanwhile, before the discharge, the fresh $\mathrm{NiCo}_{2} \mathrm{O}_{4}$-based electrode shows a rather loose morphology with macro-tunnels (Figure $7 \mathrm{~b}$ ) that can permit oxygen flow and $\mathrm{Li}_{2} \mathrm{O}_{2}$ deposition. During the $1^{\text {st }}$ discharge, the insoluble species precipitate on the surface of the cathode, and a less porous morphology was obtained compared to the pristine porous electrode before the discharge. Moreover, the band at approximately $800 \mathrm{~cm}^{-1}$ in the Raman spectrum of the electrode after discharge (Figure S6) is ascribed to $\mathrm{O}-\mathrm{O}$ stretching vibrations of lithium peroxide, further confirming the presence of lithium peroxide. ${ }^{[49]}$ After the $1^{\text {st }}$ charge, the porous structure is essentially regained for the $\mathrm{NiCo}_{2} \mathrm{O}_{4}$-based electrode, indicating a reversible reaction (Figure 7d). Since the fundamental features of the ORR and OER processes in aqueous and nonaqueous electrolytes share similarities, ${ }^{[50]}$ catalysts that can favour a $4 \mathrm{e}^{-}$electron reaction in aqueous media have been reported to easily facilitate a $2 \mathrm{e}^{-}$reaction in non-aqueous electrolyte. ${ }^{[51]}$ Thus, it is not surprising that we acquired satisfactory electrocatalytical results for our as-prepared 3D foam-like $\mathrm{NiCo}_{2} \mathrm{O}_{4}$ in terms of reversible $\mathrm{Li}_{2} \mathrm{O}_{2}$ formation and decomposition, as well as reduced discharge-charge overpotential, based on the former RDE results involving a $4 \mathrm{e}^{-}$ORR reaction and excellent OER performance. Moreover, the 3D foam-like structure not only provides more contact sites and larger space for $\mathrm{Li}_{2} \mathrm{O}_{2}$ deposition, it also simultaneously improves the transport of oxygen and electrolyte, which underpin enhanced discharge-charge capacity, as well as stable cycling capability.

\section{Conclusion}




\section{WILEY-VCH}

In summary, self-assembled 3D foam-like $\mathrm{NiCo}_{2} \mathrm{O}_{4}$ was fabricated by an environmentally friendly starch template method and demonstrated superior bi-functional electrocatalytic activity towards both the ORR and the OER when employed as the catalyst for non-aqueous lithium oxygen batteries, as compared to traditional Super P catalyst. The assembled battery shows a relatively high round-trip efficiency of $70 \%$, as well as a high discharge capacity of $10137 \mathrm{mAh} \mathrm{g}^{-1}$ at a current density of $200 \mathrm{~mA} \mathrm{~g}^{-1}$ and excellent electrochemical performance in such aspects as high rate capability and stable cycling behaviour. The specific discharge capacity at a current density of $1000 \mathrm{~mA} \mathrm{~g}^{-1}$ reaches $5598 \mathrm{mAh} \mathrm{g}^{-1}$, which is about $55 \%$ of that at the current density of $200 \mathrm{~mA} \mathrm{~g}^{-1}$. When discharge-charge capacities are limited to $1000 \mathrm{mAh} \mathrm{g}^{-1}$, the as-prepared 3D foam-like $\mathrm{NiCo}_{2} \mathrm{O}_{4}$ shows rather stable and reversible discharge-charge potentials and exhibits no capacity loss up to 80 cycles at a current density of $200 \mathrm{~mA} \mathrm{~g}^{-1}$. These encouraging results are due to the unique, hierarchically self-assembled 3D foam-like structure, which facilitates continuous oxygen flow through the large tunnels to the interior parts of the electrode and provides enough triple junctions (solid-liquid-gas) for $\mathrm{Li}_{2} \mathrm{O}_{2}$ deposition and decomposition. This study highlights the importance of a novel electrode design and opens up a promising strategy to develop highly efficient oxygen electrodes for lithium oxygen batteries.

\section{Experimental Section}

\subsection{Materials Preparation}

One gram of soluble starch was dissolved in $10.0 \mathrm{~mL}$ distilled water with stirring. Then, it was mixed with a $10 \mathrm{~mL}$ aqueous solution of nickel acetate $(0.1 \mathrm{M})$ and cobalt acetate $(0.2 \mathrm{M})$ to form a uniform suspension. The mixture was then placed in an oil bath preheated to $90{ }^{\circ} \mathrm{C}$ and maintained for 20 min under vigorous stirring until a pink gel was obtained. The gelatinized paste was kept at $90^{\circ} \mathrm{C}$ for an additional 10 min without stirring to age. After cooling to room temperature, it was then freeze-dried for $24 \mathrm{~h}$ to obtain the light pink nickel 


\section{WILEY-VCH}

acetate/cobalt acetate/starch precursor. Then, the precursor was calcined at a temperature of $380{ }^{\circ} \mathrm{C}$ with a heating rate of $5{ }^{\circ} \mathrm{C} \mathrm{min}^{-1}$ to obtain the hierarchically $3 \mathrm{D}$ foam-like $\mathrm{NiCo}_{2} \mathrm{O}_{4}$.

\subsection{Physical Characterizations}

X-ray diffraction (XRD) (GBC MMA) patterns were collected over a $2 \theta$ range of $10^{\circ}-80^{\circ}$ with a scan rate of $4^{\circ} \mathrm{min}^{-1}$ and analysed with Traces ${ }^{\mathrm{TM}}$ software in combination with the Joint Committee on Powder Diffraction Standards (JCPDS) powder diffraction files. X-ray photoelectron spectroscopy (XPS) was conducted on a VG Scientific ESCALAB 2201XL instrument using $\mathrm{Al} \mathrm{K} \alpha \mathrm{X}$-ray radiation and fixed analyser transmission mode. The XPS data were analysed using CasaXPS software, and all the results were calibrated by C 1s at 284.6 $\mathrm{eV}$ for graphite.

The morphologies of the samples were examined by field emission scanning electron microscopy (FE-SEM, JEOL 7500) and transmission electron microscopy (TEM, JEOL ARM-200F). High-angle annular dark-field (HAADF) scanning transmission electron microscope (STEM) images and corresponding element mapping images were collected with the same TEM equipped with a Centurio SSD energy-dispersive X-ray spectroscopy (EDS) detector. The Brunauer-Emmett-Teller (BET) surface area and pore size distribution were determined on a Micromeritics ASAP 2010 adsorption analyser at $196{ }^{\circ} \mathrm{C}(77 \mathrm{~K})$.

\subsection{Li- $\mathrm{O}_{2}$ Battery Measurements}

The electrochemical performances of lithium oxygen batteries were investigated using 2032 coin-type cells with air holes on the cathode side. For the preparation of the 3D foam-like $\mathrm{NiCo}_{2} \mathrm{O}_{4}$ cathode electrode, $50 \mathrm{wt} \%$ catalyst, 40 wt \% Super P, and 10 wt \% poly $(1,1,2,2-$ tetrafluoroethylene) (PTFE) were mixed in an isopropanol solution. The resulting homogeneous slurry was coated onto a gas diffusion layer (GDL). The same procedure was applied to prepare pure Super P electrodes, which consisted of 90 wt. \% Super P and 10 wt \% poly(1,1,2,2-tetrafluoroethylene) (PTFE). After that, the electrodes were dried at $120{ }^{\circ} \mathrm{C}$ in a vacuum oven for $12 \mathrm{~h}$. All the $\mathrm{Li}-\mathrm{O}_{2}$ batteries were assembled in an Ar-filled glove box 


\section{WILEY-VCH}

(Mbraun, Unilab, Germany) with water and oxygen contents below $0.1 \mathrm{ppm}$. They consisted of lithium metal foil as the counter electrode, a glass fiber separator (Whatman GF/D), noncarbonate electrolyte containing $1 \mathrm{M} \mathrm{LiCF}_{3} \mathrm{SO}_{3}$ in tetraethylene glycol dimethyl ether (TEGDME), and the air cathode electrode. All the assembled coin cells were stored in an $\mathrm{O}_{2}$ purged chamber which was connected to a LAND CT 2001 A multi-channel battery tester for $2 \mathrm{~h}$ before each test. The galvanostatic discharge-charge tests were then conducted on the battery testing system with the voltage between $2.35-4.35 \mathrm{~V}\left(\mathrm{vs} . \mathrm{Li}^{+} / \mathrm{Li}\right)$, and the capacity was calculated based on the mass of the carbon in the cathode. Cyclic voltammetry (CV) was conducted in $\mathrm{O}_{2}$ saturated $1 \mathrm{M}$ lithium trifluoromethanesulfonate $\left(\mathrm{LiCF}_{3} \mathrm{SO}_{3}\right)$ in tetraethylene glycol dimethyl ether (TEGDME). The current densities and specific capacities were calculated based on the amount of carbon in the cathodes.

\subsection{Rotating Disk Electrode Tests}

RDE tests were performed using a computer-controlled potentiostat (Princeton 2273 and 616, Princeton Applied Research) in a conventional three-electrode cell at room temperature. The glassy carbon (GC) working electrode ( $5 \mathrm{~mm}$ in diameter) was first polished with 1.0 and 0.05 $\mu \mathrm{m}$ alumina powder, rinsed with deionized water, and sonicated first in ethanol and then in double-distilled water. A platinum wire and $\mathrm{Ag} / \mathrm{AgCl}$ (saturated $\mathrm{KCl}$ filled) were used as the counter and reference electrodes, respectively. Typically, the $\mathrm{NiCo}_{2} \mathrm{O}_{4}$ was redispersed in deionized water + isopropanol $+5 \%$ Nafion $^{\circledR}(\mathrm{v} / \mathrm{v} / \mathrm{v}=4 / 1 / 0.05)$ to form a homogeneous catalyst ink with a concentration of $2 \mathrm{mg} \mathrm{mL}^{-1}$. Then, $30 \mu \mathrm{L}$ of this dispersion was pipetted onto the surface of the GC working electrode and dried under ambient conditions. For comparison, the control samples were Super P and commercial Pt/C (10 wt.\% Pt on Vulcan $\mathrm{XC}-72$ ), and were also obtained by the same method described above. Cyclic voltammograms (CVs) were collected in $\mathrm{O}_{2}$ saturated $0.1 \mathrm{M} \mathrm{KOH}$ solution from $-0.9 \mathrm{~V}-0.1 \mathrm{~V}$ at a scan rate of $10 \mathrm{mV} \mathrm{s}^{-1}$. Linear sweep voltammograms (LSVs) to measure the ORR performance were collected in $\mathrm{O}_{2}$ saturated $0.1 \mathrm{M} \mathrm{KOH}$ solution with different rotation speeds from 100 to 2500 


\section{WILEY-VCH}

rpm from - $0.9-0.1 \mathrm{~V}$ with a scan rate of $10 \mathrm{mV} \mathrm{s}^{-1}$, while OER plots were obtained in $\mathrm{Ar}$ atmosphere from $0.1-0.9 \mathrm{~V}$ with a scan rate of $10 \mathrm{mV} \mathrm{s}^{-1}$ and a rotation speed of $1600 \mathrm{rpm}$. Koutecky-Levich (K-L) plots show the inverse current density $\left(j^{-1}\right)$ as a function of the inverse of the square root of the rotation speed $\left(\omega^{-1 / 2}\right)$ at different potential values. The number of electrons involved per $\mathrm{O}_{2}$ in the ORR was determined by the Koutecky-Levich equation: ${ }^{[34]}$

$$
\frac{1}{\mathrm{j}}=\frac{1}{j_{k}}+\frac{1}{j_{d}}=\frac{1}{B \omega^{1 / 2}}+\frac{1}{j_{k}}
$$

where $\mathrm{j}, \mathrm{j}_{\mathrm{k}} \mathrm{j}_{\mathrm{d}}$ are the measured, the kinetically controlled and the diffusion controlled current densities, respectively, and $\omega$ is the electrode rotation rate. $B$ is determined from the slope of the K-L plot based on the Levich equation:

$$
B=0.2 n F\left(D_{\mathrm{O} 2}\right)^{2 / 3} v^{-1 / 6} C_{\mathrm{O} 2}
$$

where $n$ represents the number of electrons gained per $\mathrm{O}_{2}, F$ is the Faraday constant $(F=$ $\left.96485 \mathrm{C} \mathrm{mol}^{-1}\right), \mathrm{Do}_{2}$ is the diffusion coefficient of $\mathrm{O}_{2}$ in $0.1 \mathrm{M} \mathrm{KOH}\left(1.9 \times 10^{-5} \mathrm{~cm}^{2} \mathrm{~s}^{-1}\right), v$ is the kinetic viscosity $\left(0.01 \mathrm{~cm}^{2} \mathrm{~s}^{-1}\right)$, and $C_{\mathrm{O} 2}$ is the bulk concentration of $\mathrm{O}_{2}\left(1.2 \times 10^{-6} \mathrm{~mol} \mathrm{~cm}^{-}\right.$ $\left.{ }^{3}\right)$.

\section{Supporting Information}

Supporting Information is available from the Wiley Online Library or from the author.

\section{Acknowledgements}

Financial support from an Australian Research Council (ARC) Discovery Project (DP140100401) is greatly appreciated. The authors also are grateful for the use of the facilities in the UOW Electron Microscopy Center, with especial thanks to Wenbin Luo. Many thanks also go to Dr. Tania Silver for critical reading of the manuscript.

Received: ((will be filled in by the editorial staff))

Revised: ((will be filled in by the editorial staff)) Published online: ((will be filled in by the editorial staff))

[1] B. D. McCloskey, R. Scheffler, A. Speidel, D. S. Bethune, R. M. Shelby, A. C.Luntz, J. Am. Chem. Soc. 2011, 133, 18038. 


\section{WILEY-VCH}

[2] P. G. Bruce, S. A. Freunberger, L. J. Hardwick, J.-M. Tarascon, Nat. Mater. 2012, 11, 19.

[3] Z. Q. Peng, S. A. Freunberger, Y. H. Chen, P. G. Bruce, Science 2012, 337, 563.

[4] H. D. Lim, H. Song, J. Kim, H. Gwon, Y. Bae, K.Y. Park, J. Hong, H. Kim, T. Kim, Y. H. Kim, X. Lepro, R. Ovalle-Robles, R. H. Baughman, K. Kang, Angew. Chem. Int. Ed. 2014, 53, 3926.

[5] F. J. Li, T. Zhang, H. S. Zhou, Energy Environ. Sci. 2013, 6, 1125.

[6] J. Yi, K. Liao, C. Zhang, T. Zhang, F. J. Li, H. S. Zhou, ACS Appl. Mater. Interfaces 2015, 7, 10823.

[7] A. Débart, J. Bao, G. Armstrong, P. G. Bruce, J. Power Sources 2007, 174, 1177.

[8] A. Debart, J. Paterson, J. Bao, P. G. Bruce, Angew. Chem. Int. Ed. 2008, 47, 4521.

[9] K. Liao, T. Zhang, Y. Wang, F. J. Li, Z. Jian, H. Yu, H. S. Zhou, ChemSusChem 2015, 8, 1429.

[10]F. J. Li, D. M. Tang, Z. Jian, D. Liu, D. Golberg, A. Yamada, H. S. Zhou, Adv. Mater. 2014, 26, 4659.

[11]H. J. Kim, S. C. Jung, Y. K. Han, S. H. Oh, ACS Catal. 2015, 5, 73.

[12]S. J. Peng, Y. X. Hu, L. L. Li, X. P. Han, F. Y. Cheng, M. Srinivasan, Q. Y. Yan, S. Ramakrishna, J. Chen, ACS Catal. 2015, 5, 4890.

[13] Y. N. Chen, Q. Zhang, Z. Zhang, X. L. Zhou, Y. R. Zhong, M.Yang, Z. J. Xie, J. P.Wei Z. Zhou, J. Mater. Chem. A 2015, 3, 17874.

[14]Z. Zhang, L. W. Su, M. Yang, M. Hu, J. Bao, J. P. Wei, Z.Zhou, Chem. Commun., 2014, 50,776 .

[15]Z. Zhang, Y. N. Chen, J. Bao, Z. J. Xie, J. P. Wei, Z. Zhou, Part. Part. Syst. Charact. 2015, 32, 680 .

[16]Yuan, J. Li, L. Hou, X. Zhang, L. Shen, X. W. D. Lou, Adv. Func. Mater. 2012, 22, 4592.

[17]X. Yu, Z. Sun, Z. Yan, B. Xiang, X. Liu, P. Du, J. Mater. Chem. A 2014, 2, 20823.

[18]B. Sun, X. Huang, S. Chen, Y. Zhao, J. Zhang, P. Munroe, G. X. Wang, J. Mater. Chem. A 2014, 2, 12053.

[19]B. Riaz, K. N. Jung, W. Chang, K. H. Shin, J. W. Lee, ACS Appl. Mater. \& Interfaces 2014, $6,17815$.

[20]A. Cui, H. Lin, J.-B. Li, X. Li, J. Yang, J. Tao, Adv. Func. Mater. 2008, 18, 1440.

[21]Y. Jing, Z. Zhou, ACS Catal. 2015, 5, 4309.

[22]Z. Zhang, J. Bao, C. He, Y. N. Chen, J. P. Wei, Z. Zhou, Adv. Funct. Mater. 2014, 24, 6826. 


\section{WILEY-VCH}

[23]W. M. Liu, T. T. Gao, Y. Yang, Q. Sun, Z. W. Fu, Phys. Chem. Chem. Phys. 2013, 15, 15806.

[24]Y. Li, L. Zou, J. Li, K. Guo, X. Dong, X. Li, X. Xue, H. Zhang, H. Yang, Electrochimica Acta 2014, 129, 14.

[25]K. Liao, X. Wang, Y. Sun, D. Tang, M. Han, P. He, X. Jiang, T. Zhang, H. Zhou, Energy Environ. Sci. 2015, 8, 1992.

[26] Y. Shao, F. Ding, J. Xiao, J. Zhang, W. Xu, S. Park, J. G. Zhang, Y. Wang, J. Liu, J. Adv. Func. Mater. 2013, 23, 987.

[27]R. R. Mitchell, B. M., Gallant, C. V. Thompson, S-H, Yang, Energy Environ. Sci. 2011, 4, 2952.

[28]J. P. Zheng, R. Y. Liang, M. Hendrickson, E. J. Plichta, J. Electrochem. Soc. 2008, 155, A432.

[29]H. Lee, Y-J Kim, D. J. Lee, J. Song, Y. M. Lee, H-T Kim, J-K. Park, J. Mater. Chem. A 2014, 2, 11891.

[30]J. J. Xu, Z. L. Wang; D. Xu, F. Z. Meng, X. B. Zhang, Energy Environ. Sci. 2014, 7, 2213.

[31]Y. Cui, Z. Wen, Y. Liu, Energy Environ. Sci. 2011, 4, 4727.

[32]Z. L. Wang, D. Xu, J. J. Xu, X. B. Zhang, Adv. Func. Mater. 2012, 22, 3699.

[33]B. Sun, X. Huang, S. Chen, P. Munroe, G. Wang, Nano Lett. 2014, 14, 3145.

[34]B. Sun, X. Huang, S. Chen, P. Munroe, G. Wang, Angew. Chem. Int. Ed. 2012, 51, 11770.

[35]B. Zhang, Sean A. Davis, S. Mann, Chem. Mater. 2002, 14, 1369.

[36]H. Lu, M. Zheng, J. Chen, N. Li; L. Xue, J. Cao, J. Integrated Ferroelectrics 2011, 127, 128.

[37]Y. Chen, J. Cao, M. Zheng, X. Ke, H. Ji, J. Liu, G. Ji, Chem. Lett. 2006, 35, 700.

[38]J. Xiao, D. Mei, X. Li, W. Xu, D. Wang, G. L. Graff, W. D. Bennett, Z. Nie, L.V. Saraf, I. A. Aksay, J. Liu, J. G. Zhang, Nano Lett. 2011, 11, 5071.

[39]S. Ma, L. Sun, L. Cong, X. Gao, C. Yao, X. Guo, L. Tai, P. Mei, Y. Zeng, H. Xie, R. Wang, J. Phys. Chem. C 2013, 117, 25890.

[40]K. Xu, X. Huang, Q. Liu, R. Zou, W. Li, X. Liu, S. Li, J. Yang, J. Hu, J. Mater. Chem. A 2014, 2, 16731.

[41]Y. E. Roginskaya,O. Morozova, E. Lubnin, Y. E. Ulitina, G. Lopukhova, S. Trasatti, Langmuir 1997, 13, 4621. 


\section{WILEY-VCH}

[42]Q. Zhang, Y. Deng, Z. Hu, Y. Liu, M., Yao, P. Liu, Phys. Chem. Chem. Phys. 2014, 16, 23451.

[43]Q. He, Q. Li, S. Khene, X. Ren, F. E. López-Suárez, D. Lozano-Castelló, A. BuenoLópez, G. Wu, J. Phys. Chem. C 2013, 117, 8697.

[44]K. Mayrhofer, D. Strmcnik, B. B. Blizanac, V. Stamenkovic, M. Arenz, N. M. Markovic, Electrochim. Acta 2008, 53, 3181.

[45]A. J. Bard, L. R. Faulkner, Electrochemical methods: Fundamentals and applications. Wiley, New York 1980

[46]W. B. Luo, S. L. Chou, J. Z. Wang, Y. C. Zhai, H. K. Liu, Small 2015, 11, 2817.

[47]Z. Jian, P. Liu, F. Li, P. He, X. Guo, M. Chen, H. Zhou, Angew. Chem. Int. Ed. 2014, 53, 442.

[48]F. Li, D. M. Tang, Y. Chen, D. Golberg, H. Kitaura, T. Zhang, A. Yamada, H. Zhou, Nano Lett. 2013, 13, 4702.

[49]L. Johnson, C. Li, Z. Liu, Y. Chen, S. A. Freunberger, P. C. Ashok, B. B. Praveen, K. Dholakia, J.-M. Tarascon, P. G. Bruce, Nat. Chem. 2014, 6, 1091.

[50]Z. L. Wang, D. Xu, J. J. Xu, X. B. Zhang, Chem. Soc. Rev. 2014, 43, 7746.

[51]Q. Li, P. Xu, W. Gao, S. Ma, G. Zhang, R. Cao, J. Cho, H. L. Wang, G. Wu, Adv. Mater. 2014, 26, 1378. 


\section{WILEY-VCH}

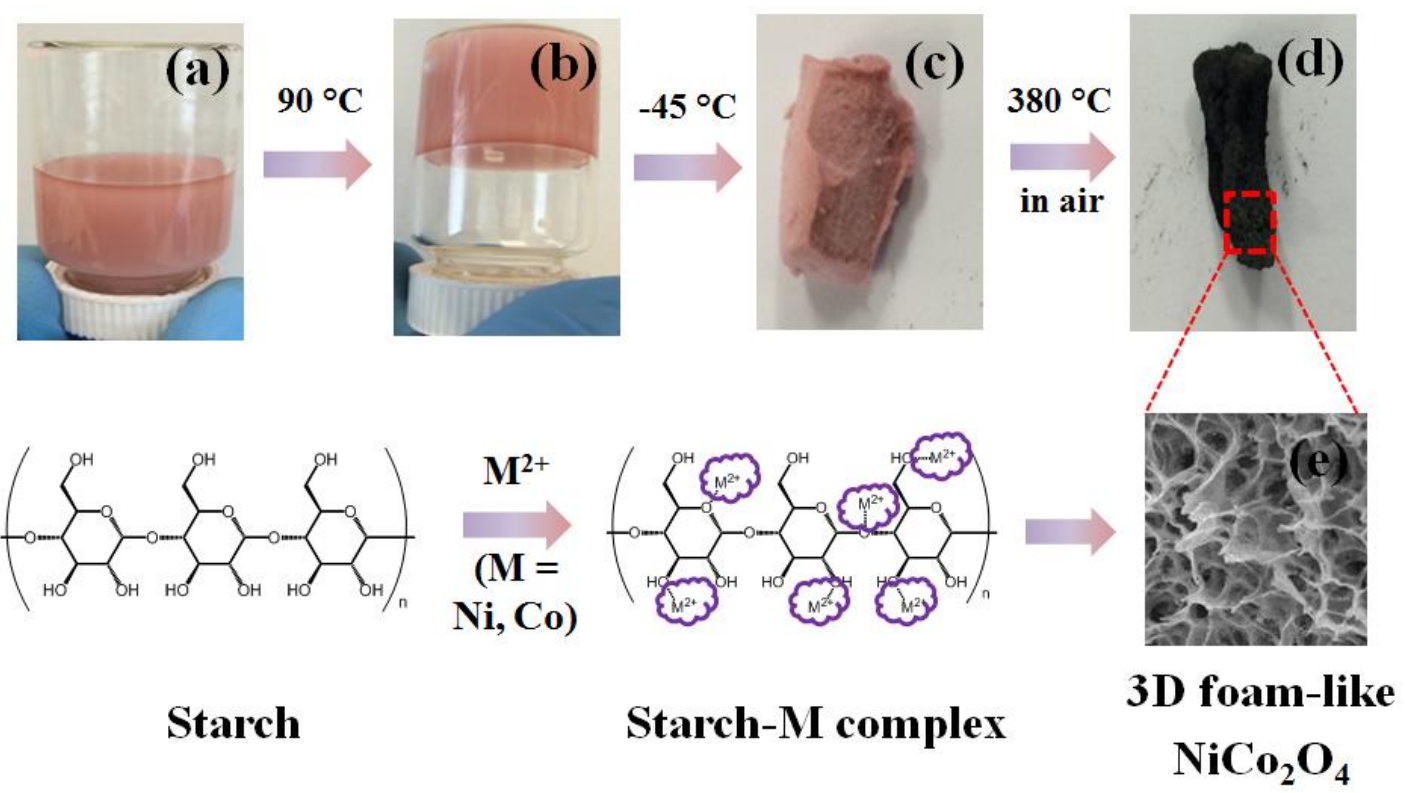

Figure 1. Schematic illustration of the preparation of the $3 \mathrm{D}$ foam-like $\mathrm{NiCo}_{2} \mathrm{O}_{4}$. a) Starch $/ \mathrm{Co}^{2+} / \mathrm{Ni}^{2+}$ aqueous suspension, b) starch $/ \mathrm{Co}^{2+} / \mathrm{Ni}^{2+}$ gel, c) $\operatorname{starch} / \mathrm{Co}^{2+} / \mathrm{Ni}^{2+}$ dry gel, d) $\mathrm{NiCo}_{2} \mathrm{O}_{4}$ calcined at $380{ }^{\circ} \mathrm{C}$ in air and e) high resolution SEM (HRSEM) image of the obtained $\mathrm{NiCo}_{2} \mathrm{O}_{4}$. 
WILEY-VCH

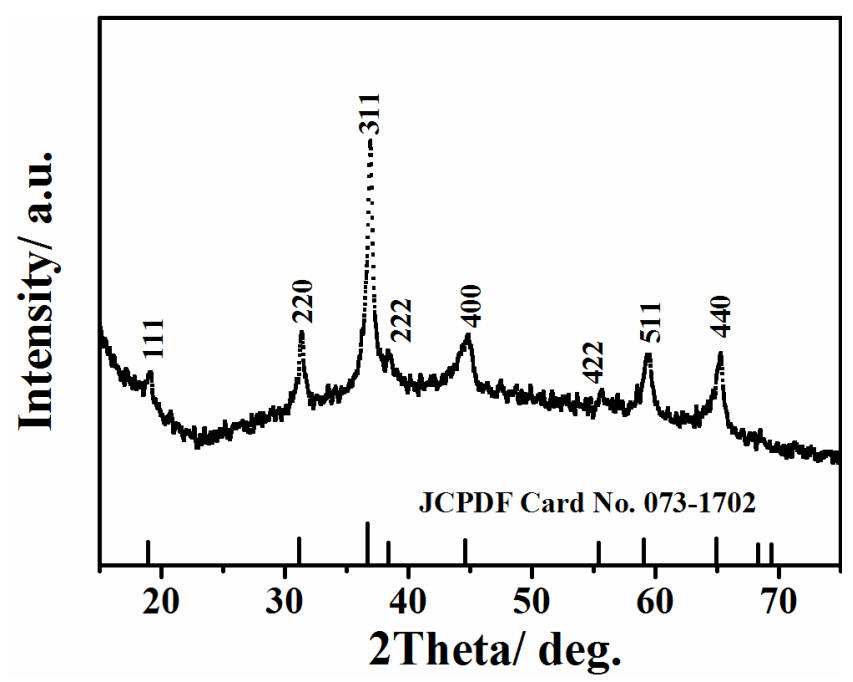

Figure 2. XRD pattern of the as-prepared 3D foam-like $\mathrm{NiCo}_{2} \mathrm{O}_{4}$. 


\section{WILEY-VCH}
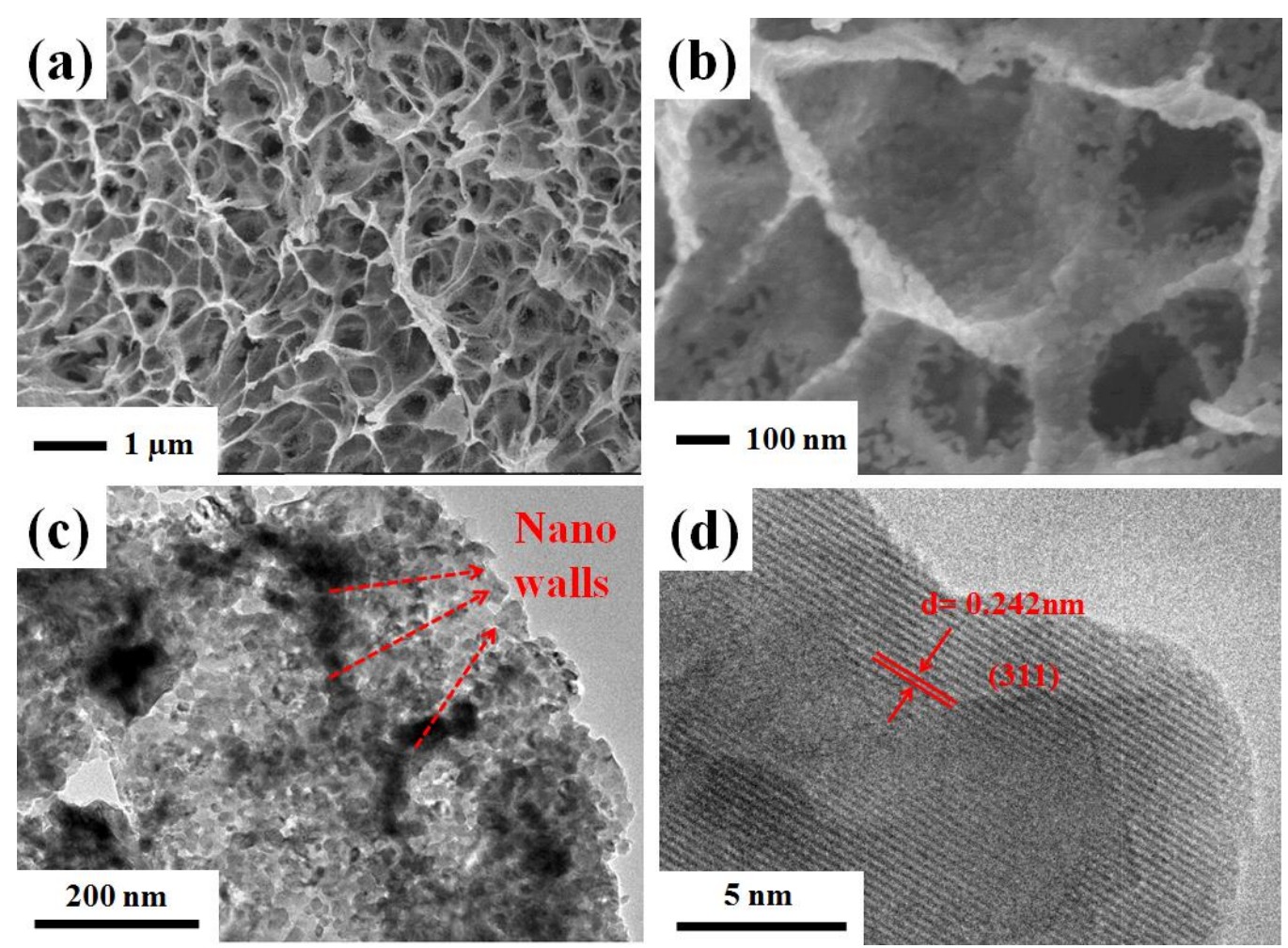

Figure 3. a,b) HRSEM images, c) TEM image, with the dashed lines indicating the nanowalls, and d) HRTEM image of the as-prepared 3D foam-like $\mathrm{NiCo}_{2} \mathrm{O}_{4}$. 


\section{WILEY-VCH}
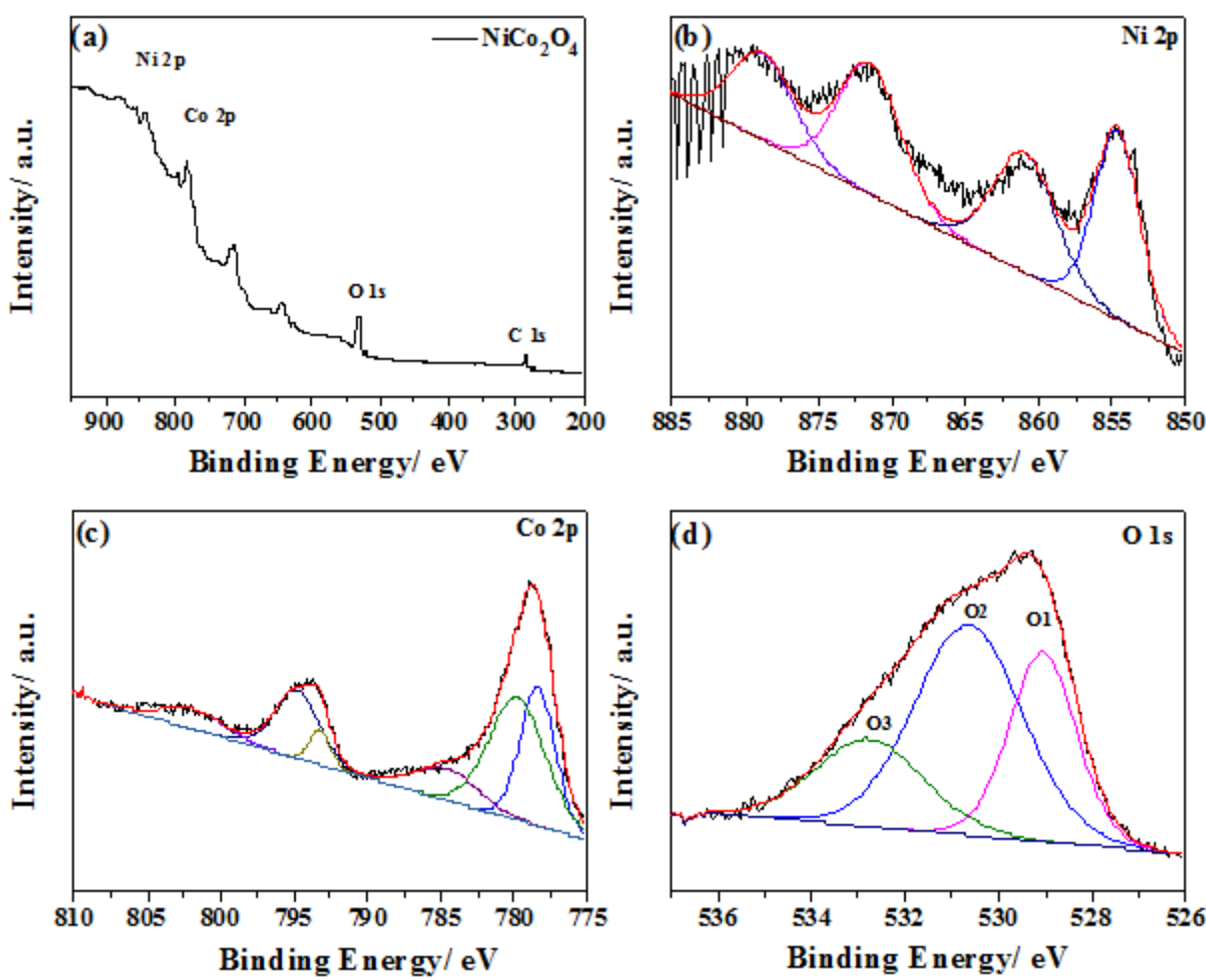

Figure 4. a) XPS survey spectrum of the as-prepared 3D foam-like $\mathrm{NiCo}_{2} \mathrm{O}_{4}$. High resolution XPS spectra of b) Ni 2p, c) Co 2p, and d) O 1s. 


\section{WILEY-VCH}
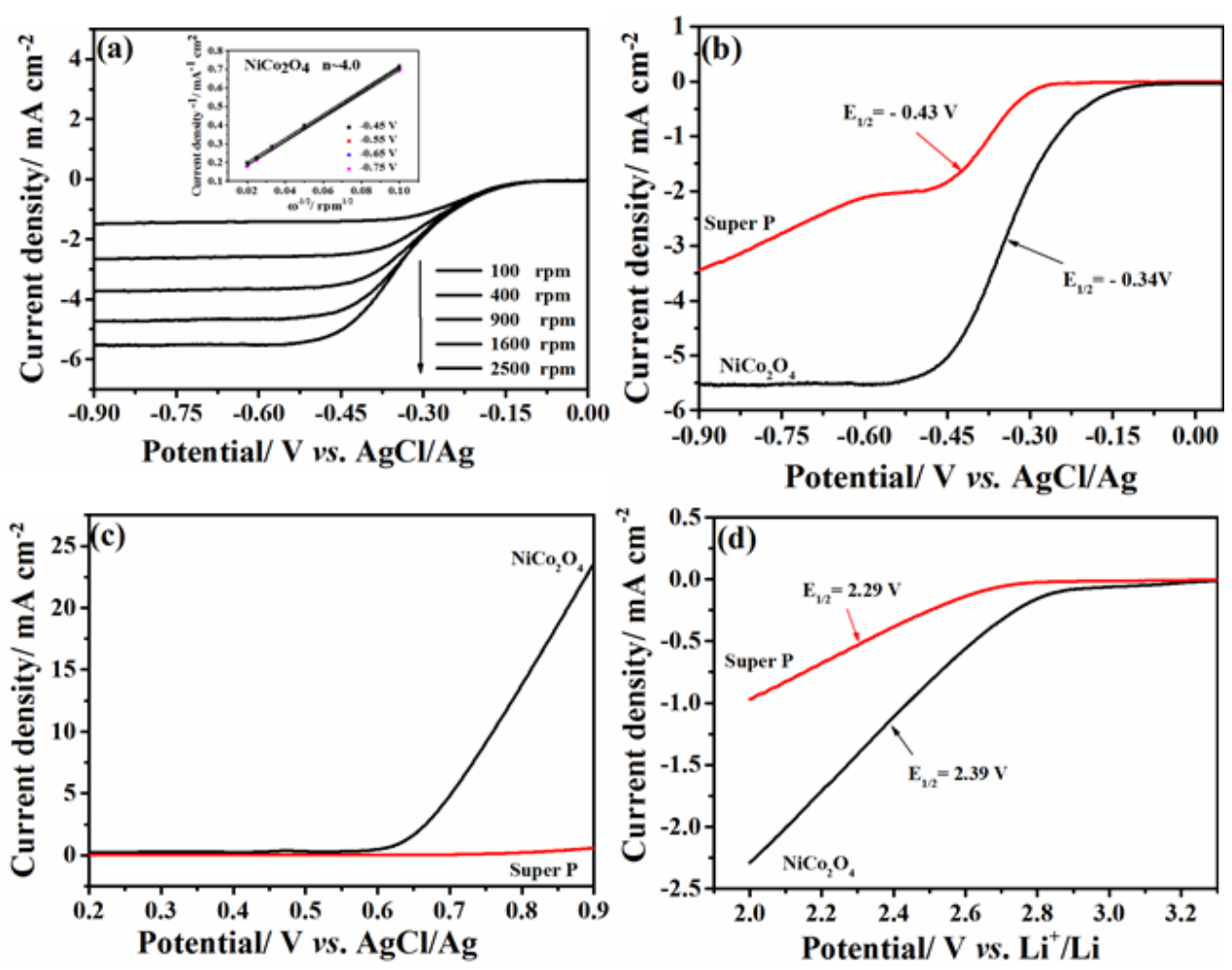

Figure 5. Linear sweep voltammetry (LSV) curves: a) the as-prepared 3D foam-like $\mathrm{NiCo}_{2} \mathrm{O}_{4}$ in $\mathrm{O}_{2}$-saturated $0.1 \mathrm{M} \mathrm{KOH}$ at a scan rate of $10 \mathrm{mV} \mathrm{s}^{-1}$ in the potential range of $-0.9-0.1 \mathrm{~V}$ (vs. $\mathrm{AgCl} / \mathrm{Ag}$ ), with the inset showing the corresponding Koutecky-Levich plots $\left(J^{-1} v s . \omega^{-0.5}\right)$. b) The as-prepared 3D foam-like $\mathrm{NiCo}_{2} \mathrm{O}_{4}$ and super $\mathrm{P}$ at a rotation speed of $1600 \mathrm{rpm}$. c) Oxygen evolution curves for the $3 \mathrm{D}$ foam-like $\mathrm{NiCo}_{2} \mathrm{O}_{4}$ and Super $\mathrm{P}$ electrodes in the potential range of 0.2-0.9 V (vs. $\mathrm{AgCl} / \mathrm{Ag}$ ). d) The as-prepared 3D foam-like $\mathrm{NiCo}_{2} \mathrm{O}_{4}$ and Super $\mathrm{P}$ at a rotation speed of $1600 \mathrm{rpm}$ in $\mathrm{O}_{2}$-saturated $0.5 \mathrm{M} \mathrm{LiCF}_{3} \mathrm{SO}_{3} / \mathrm{TEGDME}$ at a scan rate of $10 \mathrm{mV} \mathrm{s}^{-1}$ in the potential range of $2.0-3.3 \mathrm{~V}\left(v s . \mathrm{Li}^{+} / \mathrm{Li}\right)$. 
WILEY-VCH
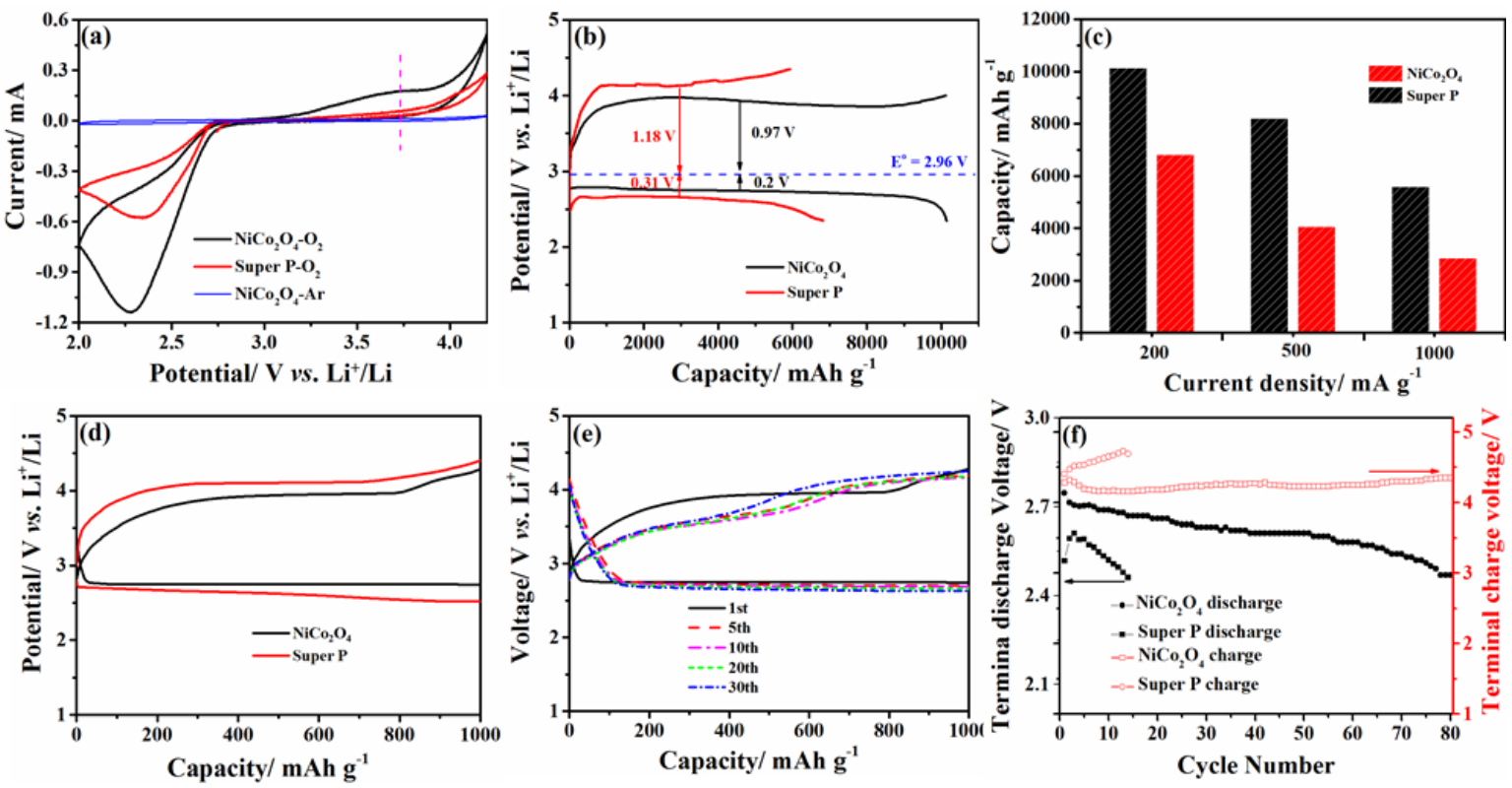

Figure 6. a) Cyclic voltammograms acquired at a scan rate of $0.2 \mathrm{mV} \mathrm{s}^{-1}$ in $1 \mathrm{M} \mathrm{LiCF}_{3} \mathrm{SO}_{3}$ in TEGDME of the as-prepared 3D foam-like $\mathrm{NiCo}_{2} \mathrm{O}_{4}$ and Super P. b) Initial discharge-charge plots of the as-prepared 3D foam-like $\mathrm{NiCo}_{2} \mathrm{O}_{4}$ and Super $\mathrm{P}$ at a current density of $200 \mathrm{~mA} \mathrm{~g}^{-1}$. c) Rate performances of the as-prepared 3D foam-like $\mathrm{NiCo}_{2} \mathrm{O}_{4}$ and Super $\mathrm{P}$ at current densities of 200, 500, and $1000 \mathrm{~mA} \mathrm{~g}^{-1}$. d) Initial discharge-charge plots of the 3D foam-like $\mathrm{NiCo}_{2} \mathrm{O}_{4}$ and Super $\mathrm{P}$ with a capacity limitation of $1000 \mathrm{mAh} \mathrm{g}^{-1}$ at a current density of 200 $\mathrm{mA} \mathrm{g}^{-1}$. e) Discharge-charge curves for selected cycles of the 3D foam-like $\mathrm{NiCo}_{2} \mathrm{O}_{4}$ with a capacity limitation of $1000 \mathrm{mAh} \mathrm{g}^{-1}$. f) Cycling performances of the $3 \mathrm{D}$ foam-like $\mathrm{NiCo}_{2} \mathrm{O}_{4}$ and Super $\mathrm{P}$ with the capacity limitation of $1000 \mathrm{mAh} \mathrm{g}^{-1}$ at a current density of $200 \mathrm{~mA} \mathrm{~g}^{-1}$. Voltage window: 2.35-4.35 V (vs. $\left.\mathrm{Li}^{+} / \mathrm{Li}\right)$. 


\section{WILEY-VCH}
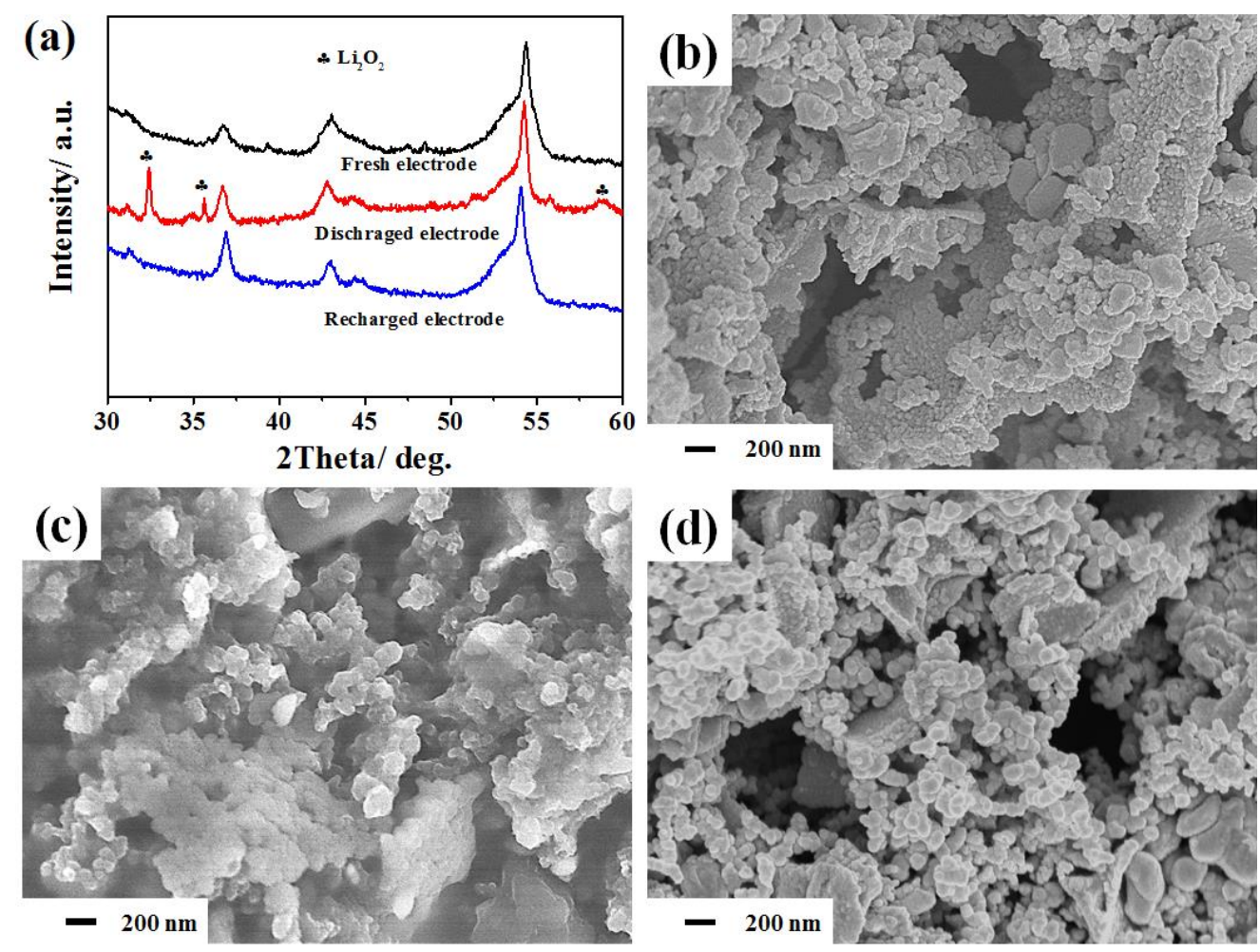

Figure 7. a) XRD patterns of the $3 \mathrm{D}$ foam-like $\mathrm{NiCo}_{2} \mathrm{O}_{4}$ cathode before discharge, after discharge, and after recharge. SEM images of b) fresh, c) discharged, and d) recharged 3D foam-like $\mathrm{NiCO}_{2} \mathrm{O}_{4}$ cathode. 


\section{WILEY-VCH}

A self-assembled three-dimensional (3D) foam-like $\mathrm{NiCo}_{2} \mathrm{O}_{4}$ catalyst has been synthesized via a simple and environmentally friendly approach. When employed as cathode for lithium oxygen batteries, it demonstrated superior bi-functional electrocatalytic activities towards both the oxygen reduction reaction and the oxygen evolution reaction, which is attributed to the synergistic benefits of the unique $3 D$ foamlike structure and the intrinsically high catalytic activity of $\mathrm{NiCo}_{2} \mathrm{O}_{4}$.

3D foam-like, ORR, OER, overpotential, $\mathrm{Li}_{2} \mathrm{O}_{2}$

Lili Liu, Jun Wang, Yuyang Hou, Jun Chen, Hua-Kun Liu, Jiazhao Wang*, and Yuping Wu*

Self-assembled 3D foam-like $\mathrm{NiCo}_{2} \mathrm{O}_{4}$ as Efficient Catalyst for Lithium Oxygen Batteries

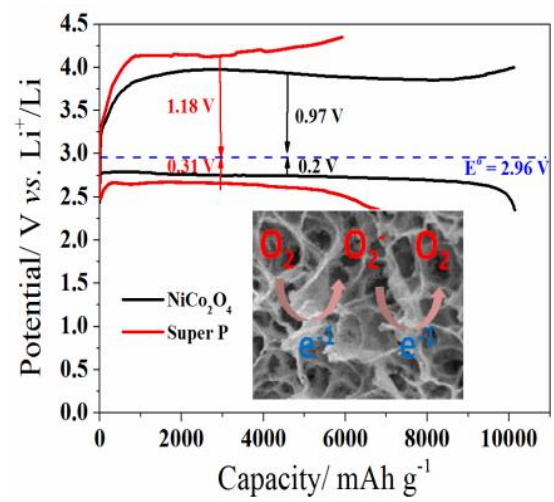




\section{WILEY-VCH}

\section{Supporting Information}

\section{Self-assembled 3D foam-like $\mathrm{NiCo}_{2} \mathrm{O}_{4}$ as Efficient Catalyst for Lithium Oxygen Batteries}

Lili Liu, Jun Wang, Yuyang Hou, Jun Chen, Hua-Kun Liu, Jiazhao Wang*, and Yuping Wu*

[*]L. Liu, Dr. Prof. Y. Wu

New Energy and Materials Laboratory (NEML), Department of Chemistry \& Shanghai

Key Laboratory of Molecular Catalysis and Innovative Materials, Fudan University,

Shanghai 200433, China

E-mail: wuyp@fudan.edu.cn

[*]L. Liu, J. Wang, Dr. Prof. H. Liu, Dr. A/Prof. J.Wang

Institute for Superconducting and Electronic Materials, University of Wollongong,

Wollongong, New South Wales 2522, Australia

E-mail: jiazhao@uow.edu.au

Y. Hou, Dr. A/Prof. J. Chen

Intelligent Polymer Research Institute, University of Wollongong, Wollongong, New South Wales 2522, Australia

Table S1. Elemental composition of the as-prepared 3D foam-like $\mathrm{NiCo}_{2} \mathrm{O}_{4}$.

\begin{tabular}{lll}
\hline Element & Weight\% & Atom\% \\
\hline Oxygen & 28.78314 & 56.04151 \\
Cobalt & 45.68487 & 26.35494 \\
Nickel & 23.73095 & 13.20083 \\
Carbon & 1.6404 & 4.21581 \\
Aluminium & 0.16064 & 0.18691 \\
Total & 100 & 100 \\
\hline
\end{tabular}

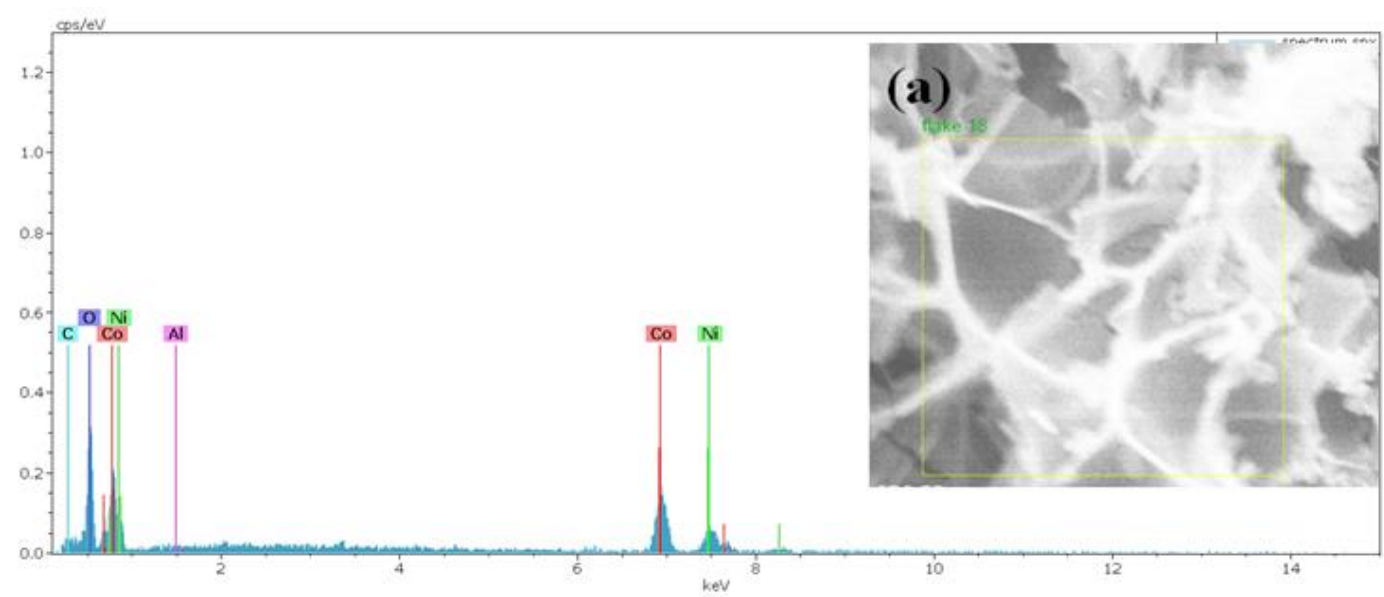

Figure S1. SEM-EDS of the as-prepared 3D foam-like $\mathrm{NiCo}_{2} \mathrm{O}_{4}$.(inset is the corresponding SEM image) 
WILEY-VCH
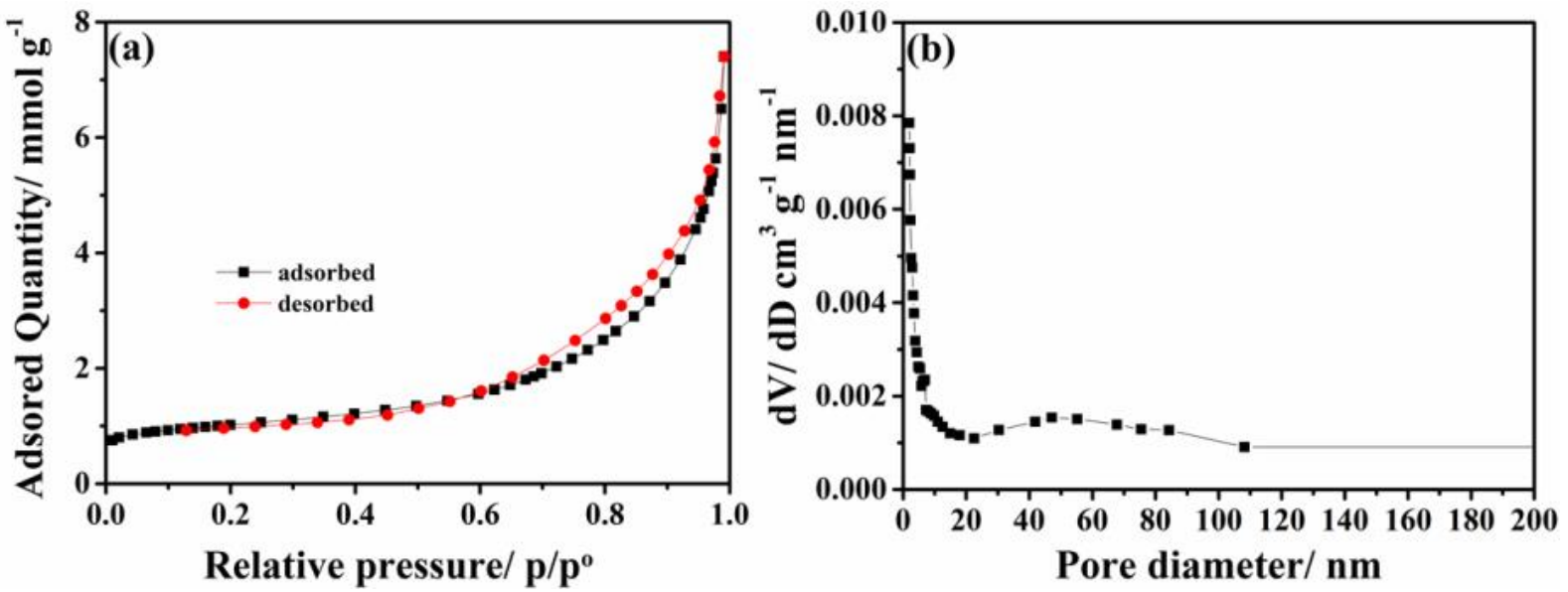

Figure S2. a) $\mathrm{N}_{2}$ adsorption-desorption isotherms and b) pore size distribution of the asprepared 3D foam-like $\mathrm{NiCo}_{2} \mathrm{O}_{4}$.
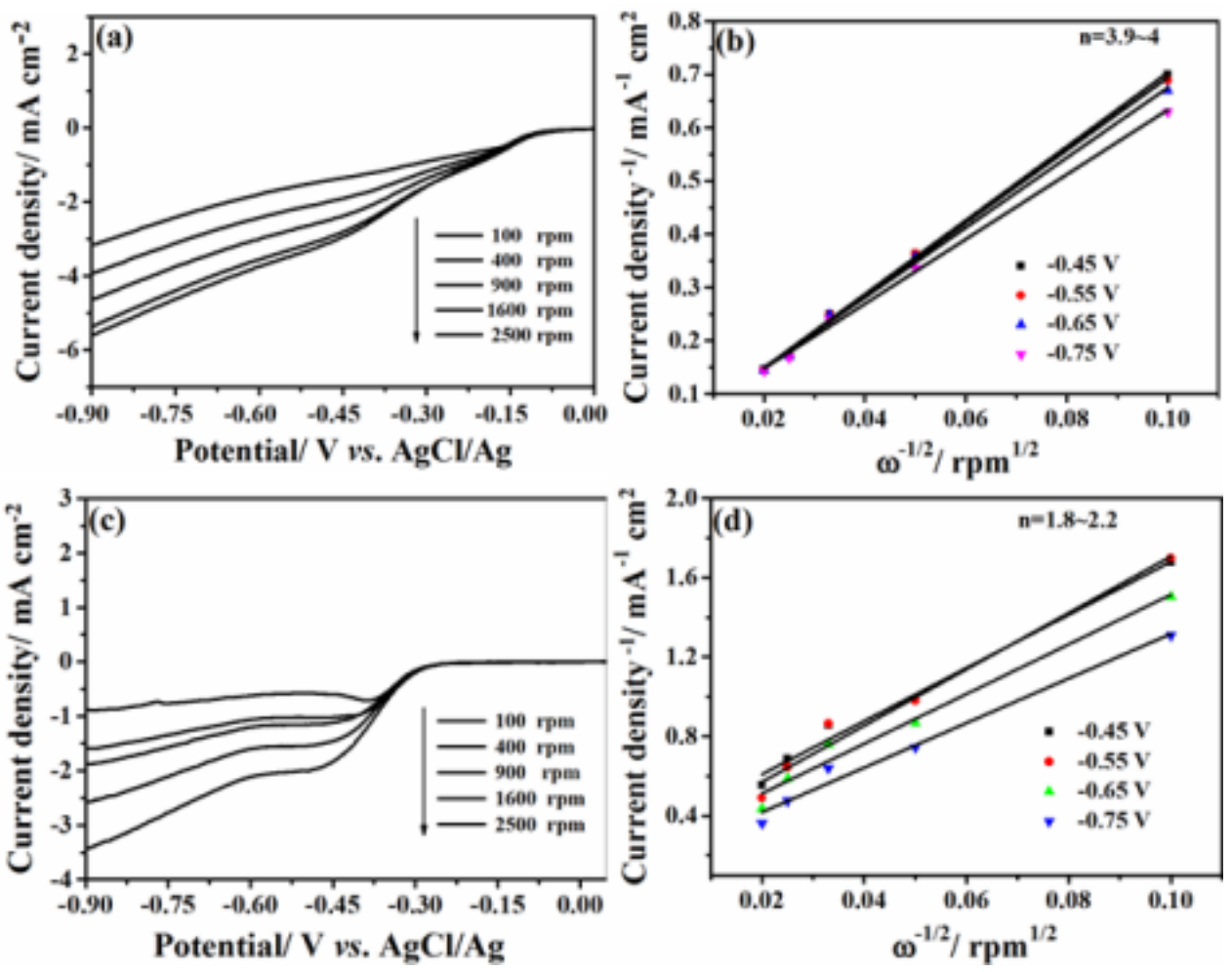

Figure S3. Linear sweep voltammetry (LSV) curves at various rotation speeds in $\mathrm{O}_{2}$-saturated $0.1 \mathrm{M} \mathrm{KOH}$ at a scan rate of $10 \mathrm{mV} \mathrm{s}^{-1}$ in the potential range of $-0.9-0.1 \mathrm{~V}$ (vs. $\mathrm{AgCl} / \mathrm{Ag}$ ) for a) $10 \% \mathrm{Pt} / \mathrm{C}$ and c) Super P; K-L plots of b) $10 \% \mathrm{Pt} / \mathrm{C}$ and d) Super P. 
WILEY-VCH

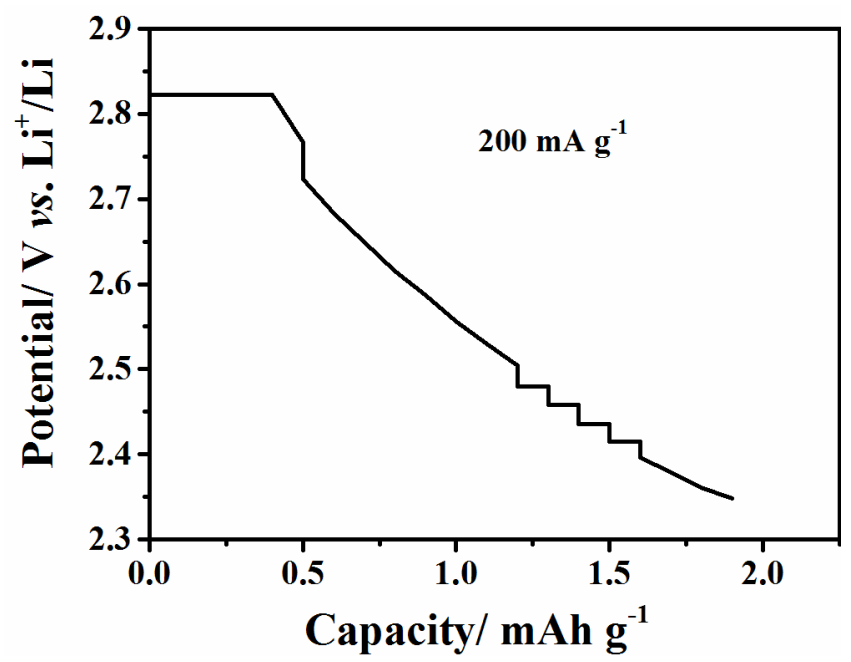

Figure S4. Discharge curve of the as-prepared 3D foam-like $\mathrm{NiCo}_{2} \mathrm{O}_{4}$ in traditional $\mathrm{R} 2032$ cells without $\mathrm{O}_{2}$ atmosphere at a current density of $200 \mathrm{~mA} \mathrm{~g}^{-1}$.
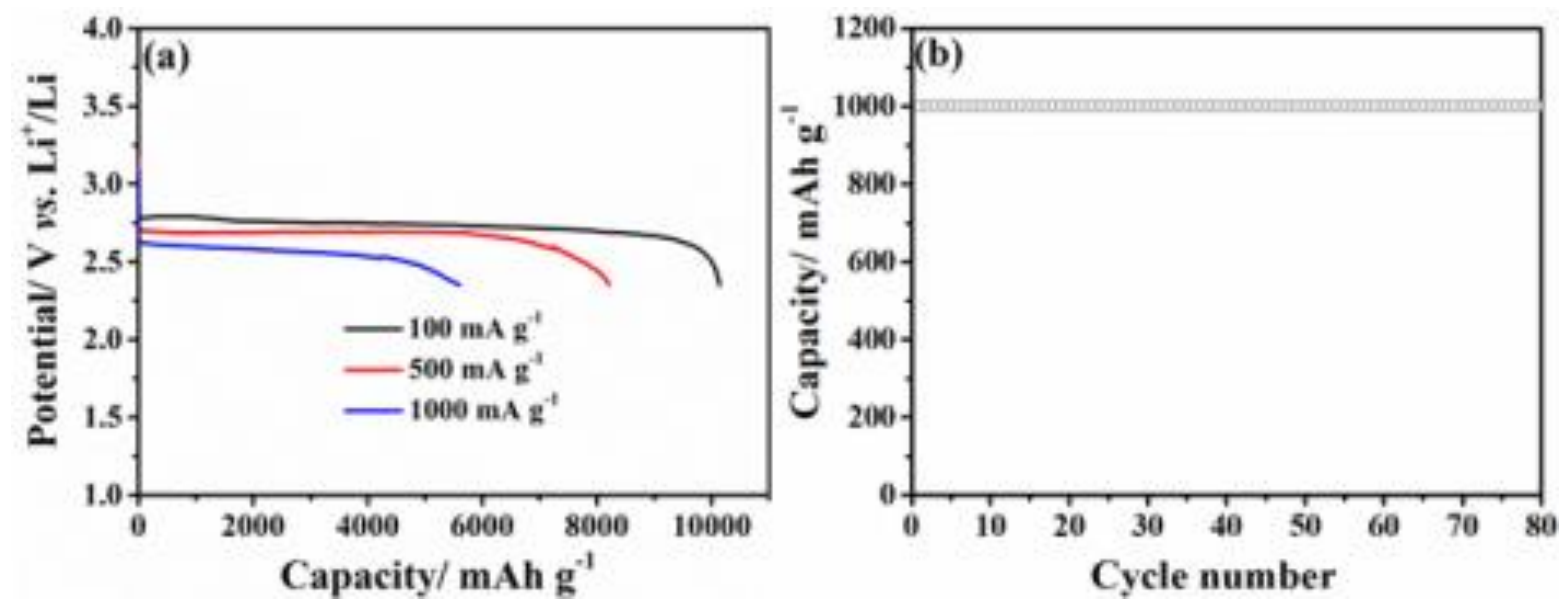

Figure S5. a) Initial discharge curves at various current densities, and b) cycling performance with a capacity limitation of $1000 \mathrm{mAh} \mathrm{g}^{-1}$ of the as-prepared 3D foam-like $\mathrm{NiCo}_{2} \mathrm{O}_{4}$. 


\section{WILEY-VCH}

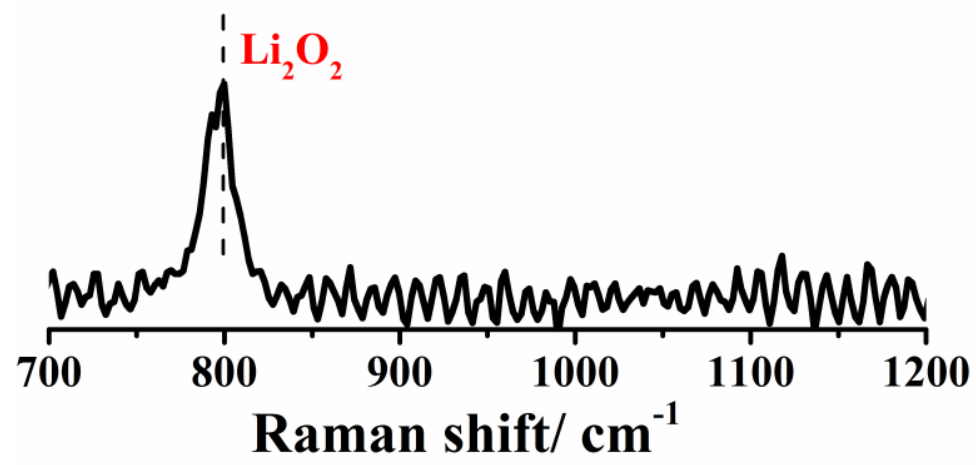

Figure S6. Raman spectrum of the discharged 3D foam-like $\mathrm{NiCo}_{2} \mathrm{O}_{4}$ cathode. 